\title{
CFD simulation of outdoor ventilation of generic urban configurations with different urban densities and equal and unequal street widths
}

\author{
Rubina Ramponi* $^{(a, b)}$, Bert Blocken ${ }^{(a, c)}$, Laura B. de Coo ${ }^{(a)}$, Wendy D. Janssen ${ }^{(a)}$ \\ (a) Building Physics and Services, Department of the Built Environment, Eindhoven University of Technology, P.O. \\ box 513, 5600 MB Eindhoven, the Netherlands \\ (b) Architecture, Built Environment, Construction Engineering Department, Politecnico di Milano, via Ponzio 31, \\ 20133 Milano, Italy \\ (c) Building Physics Section, Department of Civil Engineering, Kasteelpark Arenberg 40 - bus 2447, \\ 3001 Leuven, Belgium
}

\section{Highlights}

- A detailed literature review of outdoor ventilation studies performed with CFD is presented.

- This review shows a lack of studies for generic urban configurations with unequal street widths.

- Here: new CFD simulations for generic configurations with equal and unequal street widths

- For most wind directions, the main street is generally beneficial for ventilation of downstream region.

- For wind parallel to main street, main street is generally not beneficial for ventilation of downstream region.

\section{Graphical abstract}

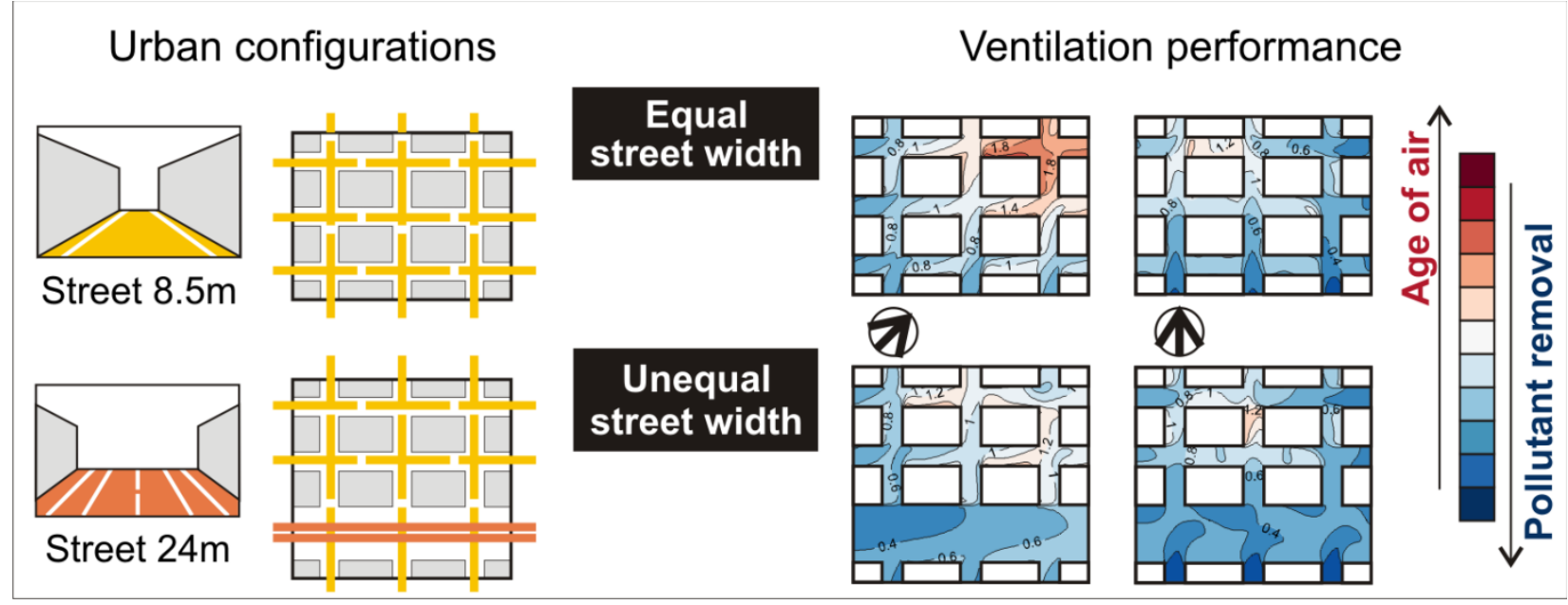

\footnotetext{
* Corresponding author: Rubina Ramponi, Building Physics and Services, Department of the Built Environment, Eindhoven
} University of Technology, P.O. Box 513, 5600 MB Eindhoven, the Netherlands. E-mail address: rubina.ramponi@gmail.com 


\title{
CFD simulation of outdoor ventilation of generic urban configurations with different urban densities and equal and unequal street widths
}

\author{
Rubina Ramponi* $^{(a, b)}$, Bert Blocken ${ }^{(a, c)}$, Laura B. de Coo ${ }^{(a)}$, Wendy D. Janssen ${ }^{(a)}$ \\ (a) Building Physics and Services, Department of the Built Environment, Eindhoven University of Technology, P.O. \\ box 513, 5600 MB Eindhoven, the Netherlands \\ (b) Architecture, Built Environment, Construction Engineering Department, Politecnico di Milano, via Ponzio 31, \\ 20133 Milano, Italy \\ (c) Building Physics Section, Department of Civil Engineering, Kasteelpark Arenberg 40 - bus 2447, \\ 3001 Leuven, Belgium
}

\begin{abstract}
Outdoor ventilation is very important for a healthy and livable urban environment. It is strongly influenced by wind speed and direction, which in turn are affected by urban morphology. This paper first provides a detailed review of the literature for CFD studies of outdoor ventilation for generic urban configurations. The review indicates that there is a clear lack of studies for urban configurations where not all parallel streets have equal street widths. Next, the paper presents Computational Fluid Dynamics (CFD) simulations of outdoor ventilation for generic configurations with parallel streets of equal and unequal street widths. The 3D steady RANS equations with the standard k- $\varepsilon$ model and the passive scalar transport equation are used to calculate the effective local mean age of air at pedestrian level as an indicator of pollutant removal efficiency. The study is based on grid-convergence analysis and on validation with previously published wind-tunnel measurements. The influence of a central and wider main street on the windvelocity pattern and on the effective local mean age of air of the surrounding area is analyzed for different wind directions. For wind directions oblique or perpendicular to the main street, the presence of this main street generally improves the ventilation efficiency because the main street acts as a sink of clean air. However, this is generally not the case for the parallel wind direction, where the higher flow rate through the main street reduces the flow rates through the parallel narrower streets, negatively affecting their ventilation efficiency.
\end{abstract}

Keywords: Urban wind flow; Building aerodynamics; Urban physics; CFD; Ventilation efficiency; Natural ventilation.

\section{Introduction}

Outdoor air pollution is one of the major environmental problems today. Urban areas are characterized by a wide range of pollutant sources such as building Heating, Ventilation and Air Conditioning (HVAC) systems, traffic, industry, etc. Urban air pollution is associated with a broad spectrum of acute and chronic health effects [1]. Ventilation of urban areas by wind flow is very important for both outdoor and indoor air quality. Outdoor air quality can be improved by wind flow because the wind can dilute and remove pollutants [2-13]. The outdoor air quality also affects the indoor air quality by mechanical and/or natural ventilation, where indoor air is replaced by outdoor air [14-20]. On the other hand, in highly ventilated areas, the wind comfort and wind safety of pedestrians can be negatively affected [21-23]. Therefore, in every practical situation a compromise needs to be found between urban ventilation for outdoor and indoor air quality on the one hand and pedestrian wind comfort and wind safety on the other hand.

Urban wind flow is strongly related to urban morphology as a combination of urban density, the mutual arrangement of buildings and their individual shape and dimensions. Urban density can be described with geometric parameters like the plan area density $\left(\lambda_{\mathrm{P}}\right)$ and the frontal area density $\left(\lambda_{\mathrm{F}}\right)$ (Fig. 1). Past studies have related these parameters to different flow regimes, from isolated obstacle flow over wake interference flow to skimming flow [2426].

\footnotetext{
* Corresponding author: Rubina Ramponi, Building Physics and Services, Department of the Built Environment, Eindhoven University of Technology, P.O. Box 513, 5600 MB Eindhoven, the Netherlands. E-mail address: rubina.ramponi@gmail.com
} 
Urban wind flow can be assessed by full-scale measurements, reduced-scale wind-tunnel experiments or by numerical simulation with Computational Fluid Dynamics (CFD). Each method has its particular advantages and disadvantages. Full-scale measurements suffer from the inherently uncontrollable and unsteady meteorological conditions [27-29]. In addition, they are usually only performed in a few discrete positions and do not provide a whole image of the flow field. Reduced-scale experiments in atmospheric boundary layer wind tunnels allow full control over the initial and boundary conditions of the experiments, but are generally only performed at a few selected points in the urban model. In addition, they can suffer from potentially incompatible similarity requirements. Like wind-tunnel testing, also CFD allows full control over the initial and boundary conditions. But in addition CFD also provides whole-flow field data, i.e. data on the relevant parameters in all points of the computational domain. Unlike wind tunnel testing, CFD does not suffer from potentially incompatible similarity requirements because simulations can be conducted at full scale. CFD simulations easily allow parametric studies to evaluate alternative design configurations, especially when the different configurations are all a priori embedded within the same computational domain and grid (see e.g. [30]). However, the accuracy and reliability of CFD are important concerns and solution verification and validation studies are imperative. The experimental data for validation in turn need to satisfy important quality criteria [27,28].

In the past 50 years, CFD has evolved into an increasingly used assessment method in urban physics and computational wind engineering [31]. It is applied for a wide range of topics, as outlined in several review papers [7,11,20-22,31-40]. Especially in the past 10 years, CFD has been increasingly employed for studies of outdoor urban ventilation. Such studies can be performed for simplified generic (or idealized) urban geometries or for real and more complex case studies. Simplified generic geometries, often composed of regular arrays of obstacles, are mostly used for systematic investigations into general correlations between aerodynamic and geometric parameters [9,10,12,41-57]. A detailed review of the literature on outdoor ventilation studies with CFD for generic urban geometries is provided in Section 2 of this paper.

In the past, different parameters have been proposed and used to evaluate the ventilation performance of urban areas. Most of those parameters were adopted from indoor ventilation studies [16-19,29,58-63] such as purging flow rate, visitation frequency, average residence time, local mean age of air, air change rate and air exchange efficiency, all of which can be calculated using CFDThe purging flow rate (PFR) is the effective airflow rate required to purge pollutants from the domain. A small purging flow rate means that the domain is weakly ventilated. The visitation frequency (VF) is the number of times a pollutant enters the domain and passes through it. A high visitation frequency indicates poor removal efficiency of the pollutants. The residence time (TP) is the time a pollutant takes from once entering or being generated in the domain until leaving the domain. Higher values again indicate poor removal efficiency of the pollutants. The local mean age of air $\left(\tau_{\mathrm{p}}\right)$ is a statistical measure of the time it takes for a parcel of air to reach a given point in the flow field after entering this flow field. For urban wind flow, it can be defined as the time it takes for the external "fresh" air to reach a given location in the urban canopy layer after entering this urban canopy layer [9]. A large mean age of air implies a poorly ventilated region: air parcels take a long time to reach a given position in the flow field and as a result pollutant removal will be slower. This, in turn, implies an accumulation of pollutants and a larger pollutant concentration. The air change rate (ACH) refers to the frequency with which a given volume of air is completely replaced by "fresh" air. The air exchange efficiency $\left(\varepsilon_{\mathrm{a}}\right)$ refers to the efficiency of airflow flushing a volume with external "fresh" air. In addition to the above-mentioned parameters for outdoor ventilation studies, Bentham and Britter [64] proposed the "exchange velocity" to analyze the outdoor ventilation in urban canopies and in particular the air exchange between the in-canopy and abovecanopy flows. The exchange velocity has been often used $[12,65,66,67,68]$ as a measure of the so-called "city breathability", a concept introduced by Neophytou and Britter [65] to express the potential of a city to "remove and dilute heat, pollution and scalars".

As will be shown in the literature review in Section 2, the large number of CFD studies on outdoor ventilation in generic urban geometries have provided a very large amount of valuable information. However, it is quite remarkable that none of them considered urban configurations consisting of different parallel streets with unequal street width. Because many urban areas, especially in Europe, are characterized by parallel streets with unequal street widths (e.g. London [67] in the UK, Eindhoven [23,40], Amsterdam [30,72] and Rotterdam in the Netherlands [75] and Antwerp in Belgium [73]), the present paper focuses on the impact of unequal street width on outdoor ventilation. The paper is based on CFD simulations because of their above-mentioned advantages, in particular the acquisition of whole-flow field data, the avoidance of potentially incompatible similarity requirements and the ease with which easily parametric studies can be performed. 3D steady simulations based on the Reynolds-Averaged Navier-Stokes (RANS) equations are performed for isothermal and incompressible flow for different generic urban configurations characterized by different plan area densities $\left(\lambda_{\mathrm{P}}\right)$ and frontal area densities $\left(\lambda_{\mathrm{F}}\right)$ and by equal and unequal street widths. The ventilation performance is assessed by means of the local mean age of air at pedestrian 
level for different wind directions ranging from $0^{\circ}$ to $90^{\circ}$. The local mean age of air is selected as evaluation parameter because it is one of the most commonly used parameters for indoor ventilation - and it is hence wellknown - and because it has also often been used in previous studies on outdoor ventilation $[10,12,42,47,55,56]$, as shown by the literature review in Section 2. Additional specific features of this study are the detailed grid-sensitivity analysis and the CFD validation.

The paper is structured as follows: Section 2 presents the literature review on CFD studies of outdoor ventilation for generic urban areas. In section 3, the urban configurations for the present study are described. The procedure to calculate the normalized local mean age of air is outlined in Section 4. The experimental data used for CFD validation are briefly presented in Section 5 . Section 5 describes the computational settings and parameters for the CFD simulations. Sections 6.1 and 6.2 report the results of the grid-sensitivity analysis and the CFD validation. The impact of the central main street on the velocity-vector field at pedestrian level and on the ventilation performance of the urban configurations is evaluated and discussed in Sections 6.3 and 6.4. Finally, some limitations of the study and conclusions are pointed out in Sections 7 and 8.

\section{Literature review on CFD studies of outdoor ventilation for generic urban geometries}

Table 1 presents an overview of a large number of previous CFD studies in which the relationship between outdoor ventilation and urban morphology was investigated based on integral parameters, rather than only velocity, turbulent kinetic energy and pollutant concentration. Some main features and findings of each of these studies are briefly mentioned below.

Skote et al. [41] analyzed a highly idealized city model consisting of a circular block divided into two or four equally large sectors. They studied two types of cases, one with only one street through the city model and one with also a perpendicular crossing street. They favorably compared their 3D steady RANS CFD simulations of the velocity magnitude in the street with wind tunnel measurements, and concluded that the CFD method is a valuable tool for quantifying the urban wind environment. Liu et al. [42] performed LES simulations to study the effect of street canyon aspect ratio $(\mathrm{h} / \mathrm{b}=0.5,1.0$ and 2.0$)$ on pollutant exchange rates, finding better canyon ventilation as the aspect ratio decreased, in line with previous studies. Li et al. [43] also focused on idealized street canyons with $\mathrm{h} / \mathrm{b}=0.5,1.0$ and 2.0. They successfully compared 2D steady RANS simulations with the RNG $\mathrm{k}-\varepsilon$ model with LES and wind tunnel results. They stressed the good agreement between the RANS and LES results and the remarkable saving in computer resources and computation time by the RANS approach. Blocken et al. [44] analyzed the flow rates through passages between parallel buildings with 3D steady RANS and the realizable k- $\varepsilon$ model. The CFD results showed a close agreement with corresponding wind tunnel measurements, with deviations that were generally below $10 \%$. The passage flow rates were related to the overall building dimensions and it was shown how the building and passage geometry decrease the flow rate through the passage compared to free-field conditions. Bady et al. [45] performed 3D steady RANS simulations with the standard k- $\varepsilon$ model for three cases: a two-building model with varying street width, an array of aligned buildings and an array of staggered buildings. Outdoor ventilation was evaluated with the PFR, the VF and the TP, where each of these three parameters was found to yield similar conclusions about the ventilation efficiency and each of them were therefore labeled as valuable parameters for assessment of outdoor air quality. Blocken et al. [46] studied the flow through passages in converging and diverging two-building arrangements with $3 \mathrm{D}$ steady RANS and the realizable k- $\varepsilon$ model, with particular attention to relating mean velocity and passage flow rates to building and passage geometry. The CFD results of mean velocity showed a very close agreement (within 10\%) with the corresponding wind tunnel measurements. Cheng et al. [47] focused on 2D street canyons with aspect ratios $\mathrm{h} / \mathrm{b}=0.5,1.0$ and 2.0, for which they performed 2D steady RANS CFD simulations with the RNG k- $\varepsilon$ model. Their results indicated that generally, consistent conclusions about the ventilation efficiency are obtained whether using $\mathrm{ACH}, \mathrm{PCH}$ or $\tau_{\mathrm{p}}$ (the pollutant retention time), except for the canyon with $\mathrm{h} / \mathrm{b}=0.5$ for which an anomaly was observed. Bu et al. [48] applied 3D steady RANS for an idealized street canyon and successfully related local air change rate and local kinetic energy. Hang et al. $[9,10,49,50]$ provided a series of important contributions relating idealized urban morphology with wind conditions and ventilation efficiency, all using the 3D steady RANS approach with the standard and/or RNG k- $\varepsilon$ model. In one of these studies, they showed that the mean age of air and the exchange efficiency do not necessarily give the same ranking of urban configurations in terms of better ventilation efficiency. Later, Hang and $\mathrm{Li}[51,52]$ extended this work by focusing in particular on aligned arrays of buildings, based on a successful validation of 3D steady RANS CFD simulations of mean wind speed with wind tunnel measurements. Buccolieri et al. [12] reported 3D steady RANS simulations with the standard k- $\varepsilon$ model for aligned arrays of cubes with a wide range of packing area densities $\lambda_{\mathrm{p}}$, to represent configurations from urban sprawl to compact cities. They found the local mean age of air to increase substantially with increasing $\lambda_{\mathrm{p}}$. They also concluded that the local mean age of air concept is a useful tool 
to quantify the so-called city breathability. Moonen et al. [53] evaluated the ventilation potential for isolated courtyards with $\mathrm{h} / \mathrm{b}=1.0$ using 3D steady RANS and LES. For these narrow courtyards, LES was shown to yield ventilation rates that for some cases were up to almost 2 times higher than those by RANS. Hang et al. [54,55,56] provided a series of contributions that provided very clear insights in the relationships between a very wide range of urban morphologies on the one hand and their outdoor ventilation on the other hand. Each of these studies was based on successful validation of the 3D steady RANS CFD results of mean wind speed with wind tunnel measurements. It is noted however that the agreement between the CFD results and the wind tunnel measurements was less good for the parameter turbulence intensity. In Ref. [55], the term "breathability" is also mentioned, and it is assessed using the mean age of air. Finally, Lin et al. [57] provided a detailed CFD study of outdoor ventilation for generic urban morphologies with the same building area density and frontal area density but various urban sizes, building height variations, overall urban forms and wind directions with the parameters ACH and PFR. Again, the 3D steady RANS CFD simulations with the realizable $\mathrm{k}-\varepsilon$ model were successfully validated with wind tunnel experiments.

This literature review allows the following conclusions to be made:

- By far most studies were performed based on the steady RANS equations and on successful validation of these simulations with wind tunnel measurements. It is well-known that LES is intrinsically superior to steady RANS and the important limitations of the RANS approach have been reported in the literature (e.g. [31-34,40,69]). However, due to the higher computational cost and larger degree of user expertise required for LES, RANS simulations still represent the vast majority of CFD simulations of urban wind flow $[31,37,40,70]$. In spite of their limitations, RANS simulations have shown good to sometimes even very good performance for both generic urban configurations (see e.g. studies in Table 1) and more complex urban configurations [5,23,29-31,7075]. These statements are confirmed by the literature review in Table 1 and especially the successful validation of the 3D steady RANS equations in these studies. Therefore, the present paper will also adopt the steady RANS approach.

- None of the studies in the literature review considered the case of urban configurations where not all parallel streets have equal street widths. Therefore, the remainder of this paper will focus explicitly on the analysis of outdoor ventilation for generic configurations with parallel streets of equal and unequal street widths.

- Several of the studies in Table 1 used the parameter local mean age of air to assess ventilation performance, and two of them explicitly assess city breathability using this parameter. For these reasons and the reasons mentioned in Section 1, the present paper will also adopt this parameter.

\section{Urban configurations}

Two different sets of urban configurations are defined by considering regular arrays of rectangular buildings with a plan area of $16 \times 24 \mathrm{~m}^{2}$ and with variable heights: $6 \mathrm{~m}, 12 \mathrm{~m}$ and $18 \mathrm{~m}$. First, the buildings are arranged as in the detailed wind-tunnel measurements by Quan et al. [76,77] that will be used for validation. The resulting plan area densities $\left(\lambda_{P}\right)$ are $0.1,0.3$, and 0.6 and the frontal area densities $\left(\lambda_{\mathrm{F}}\right)$ range from 0.02 (VS-A06) to 0.45 (VS-C18) as shown in Fig. 2. These configurations and their results are termed "VS-cases" (VS = validation study). Next, more realistic urban configurations are defined that consist of combinations of the wider main street with narrower secondary streets (Fig. 3). They are based on realistic street configurations, as shown in Table 2. The secondary streets have an equal width of $8.5 \mathrm{~m}$ and the central main street has a width of $8.5 \mathrm{~m}$ (equal street layout) or larger widths of $16 \mathrm{~m}$ or $24 \mathrm{~m}$ (unequal street layout). These configurations and their results are termed "MS-cases" (MS = main street study). The plan area density of the MS-cases is within the range of the VS-cases, being 0.48 in MS-0, 0.42 in MS-1, and 0.37 in MS-2.

\section{Calculation of the local mean age of air}

The ventilation performance of the MS-cases is evaluated by means of the local mean age of air $\left(\overline{\tau_{P}}\right)$, calculated as in Eq. 1:

$\overline{\tau_{P}}=\frac{c}{\dot{m}}$ 
where $\mathrm{c}$ is the local concentration of a passive tracer gas $\left(\mathrm{kg} / \mathrm{m}^{3}\right)$ and $\dot{m}$ is the release rate $\left(\mathrm{kg} /\left(\mathrm{m}^{3} \mathrm{~s}\right)\right)$ as generated by a homogeneous emission source within the entire domain. Homogeneous emission is important to be independent of the source location within the domain. This is generally called the "homogeneous emission method" [10,12,16,54-57]. As mentioned by Buccolieri et al. [12], Eq. 1 can be interpreted as the link between a concentration level and a time scale. If the time scale is known, the pollutant concentration from a homogeneous emission source can be estimated. A poorly ventilated region implies a large $\overline{\tau_{P}}$, i.e. air parcels take a long time to reach a given region and therefore the pollutant removal will be slower. This implies an accumulation of pollutants in this region and thus a larger pollutant concentration. $\overline{\tau_{P}}$ is calculated in the area between the buildings at the pedestrian level $(=1.75 \mathrm{~m})$ for different wind directions. In particular, an area of interest was chosen as in Fig. 4 to have two rows of upstream buildings for all wind directions, as recommended by Yoshie et al. [70] and Tominaga et al. [78], and one row of downstream buildings to limit the effects of the backflow at the leeward side of the urban configurations. Because the pollutant source was applied in the entire computational domain, the value of $\overline{\tau_{P}}$ depends on the distance from the inlet of the domain. Therefore, the local mean age of air $\left(\overline{\tau_{P}^{\prime}}\right)$ within the urban configurations was calculated as $\overline{\tau_{P}^{\prime}}=\overline{\tau_{P}}-\overline{\tau_{0}}$, where $\overline{\tau_{0}}$ is the mean value of the local mean age of air at the inlet street openings of the urban configurations (Fig. 4). For different wind angles, $\overline{\tau_{0}}=\min \left(\overline{\tau_{S 1}} ; \overline{\tau_{S 2}}\right)$ where $\overline{\tau_{S 1}}$ and $\overline{\tau_{S 2}}$ are the mean age of air at the inlet of street $\mathrm{S} 1$ and street $\mathrm{S} 2$ in Fig. 4. Finally, the normalized local mean age of $\operatorname{air}\left(\overline{\tau_{P}^{*}}\right)$ was obtained from $\overline{\tau_{P}^{\prime}}$ as in Hang et al. [9] and Buccolieri et al. [12]:

$$
\overline{\tau_{P}^{*}}=\overline{\tau_{P}^{\prime}} \frac{Q_{r e f}}{V_{r e f}}
$$

where $\mathrm{Q}_{\text {ref }}$ is the volume flow rate $\left(\mathrm{m}^{3} / \mathrm{s}\right)$ through the inlet street opening areas $\left(\mathrm{A}_{\text {ref }}\right)$ calculated far upstream of the urban configurations (Fig. 4) up to the pedestrian level height $(1.75 \mathrm{~m})$ and $\mathrm{V}_{\text {ref }}$ is the volume $\left(\mathrm{m}^{3}\right)$ of air in the area between the buildings up to the pedestrian level. To estimate the spatial-frequency distribution of the local mean age of air, 120 sampling points were distributed in the area of interest as shown in Fig. 4.

\section{Experimental data for CFD validation}

The experimental data used for validation were provided by Quan et al. [76,77] and obtained in the atmospheric boundary layer (ABL) wind tunnel of Tokyo Polytechnic University (TPU). The wind tunnel has a test section of 2.2 $\mathrm{x} 1.8 \mathrm{~m}^{2}$ and the urban configurations, scaled 1:100, were placed at the turntable with a diameter of $2 \mathrm{~m}$. The ABL profile at a scale of 1:3 represented suburban terrain corresponding to terrain category III in the AIJ recommendations [79]. It was generated by placing roughness elements and a carpet upstream of the turntable, yielding an aerodynamic roughness length $\mathrm{z}_{0}=0.002 \mathrm{~m}$ in reduced-scale $(0.2 \mathrm{~m}$ in full-scale). At the height of $0.1 \mathrm{~m}$ ( $10 \mathrm{~m}$ in full-scale), a mean wind speed of $7.8 \mathrm{~m} / \mathrm{s}$ and a longitudinal turbulence intensity of $25 \%$ were measured, while at $0.5 \mathrm{~m}(50 \mathrm{~m}$ in full-scale) the mean wind speed was about $12 \mathrm{~m} / \mathrm{s}$ and the turbulence intensity $20 \%$. From the experiments, a logarithmic profile was fitted and extrapolated to larger height to be used as inlet profile for the numerical simulations, as reported in Sect. 5.2.

The experimental data consisted of the wind pressure coefficients on the surfaces of the central building (black building in Fig. 2). The wind pressure was measured with pressure taps arranged every $20 \mathrm{~mm}$ on each of the building surfaces and connected to a Scanivalve pressure measurement system through synthetic resin tubes. The pressure coefficients $\left(C_{p}\right)$ on the surfaces of the central building were calculated as in Eq. 3, where $P_{x}$ is the static pressure at a given location $\mathrm{x}$ on the building facade, $\rho$ is the air density and $\mathrm{U}_{\text {ref }}$ is the upstream reference mean wind speed measured at $10 \mathrm{~m}$ height $\left(\mathrm{U}_{\text {ref }}=7.8 \mathrm{~m} / \mathrm{s}\right)$.

$$
C_{P}=\frac{P_{x}}{0.5 \rho U_{r e f}^{2}}
$$


Given the strong coupling between the mean velocity field and the mean pressure field, a validation study based on the available pressure coefficients is considered appropriate. In addition, earlier studies showed that 3D steady RANS with a relatively simple linear k- $\varepsilon$ type model can provide accurate results of mean wind speed in generic urban configurations (see Section 2 and Table 1).

\section{CFD simulations: computational settings and parameters}

\subsection{Computational domain and grid}

For the VS-cases, only the downstream length of the computational domain was determined according to the best practice guidelines by Franke et al. [80] and Tominaga et al. [78]. The upstream length was reduced to 3 times the maximum height of the buildings (i.e. $0.18 \mathrm{~m}$ in reduced-scale or $18 \mathrm{~m}$ in full-scale) to reduce the development of unintended streamwise gradients $[44,81]$. Furthermore, because the wind-tunnel blockage ratio was very high for some cases, e.g. up to $6.5 \%$ for VS-C18, the cross section of the computational domain was taken equal to the wind-tunnel cross-section. The resulting size of the computational domain for the VS-cases was $\mathrm{W}_{\mathrm{D}} \times \mathrm{D}_{\mathrm{D}} \times \mathrm{H}_{\mathrm{D}}=5.2$ x $2.2 \times 1.8 \mathrm{~m}^{3}$ in reduced-scale $\left(520.2 \times 220 \times 180 \mathrm{~m}^{3}\right.$ in full-scale). For the MS-cases, the width, height and downstream length of the computational domain were defined in accordance to the best practice guidelines, while the upstream length was again taken 3 times the maximum height of the buildings, resulting in dimensions $W_{D} \times D_{D}$ $\mathrm{x} \mathrm{H}_{\mathrm{D}}=536 \times 392 \times 180 \mathrm{~m}^{3}$.

In order to provide maximum control over the grid topology and grid quality, the grid was first generated in the ground plane and then extruded in the third dimension according to the surface-grid extrusion technique presented by van Hooff and Blocken [30]. The resulting grid only consists of hexahedral cells, and satisfies best practice guidelines for high quality grid generation $[40,78,82,83]$. For both VS-cases and MS-cases, the computational domain was split in two parts, i.e. a central subdomain and an external subdomain, as shown in Fig. 5 for the VScases. This way, only the central subdomain and grid need to be varied for different cases and wind directions, while the external subdomain and its grid remain identical. A grid-sensitivity analysis was performed for case VS-B18 by refining and coarsening the grid by about a factor 2 and its results are reported in Sect. 6.1. The generation of the other grids was based on the results of this grid-sensitivity analysis, yielding the total cell counts reported in Table 3 .

\subsection{Boundary conditions and solver settings}

The inlet profiles of mean wind speed $\mathrm{U}$, turbulent kinetic energy $\mathrm{k}$ and turbulence dissipation rate $\varepsilon$ were identical for all simulations. A logarithmic mean speed profile was fitted to the measured profile using Eq. 4 where $\mathrm{u}^{*}{ }_{\mathrm{ABL}} / \mathrm{U}=0.11 \mathrm{~m} / \mathrm{s}, \mathrm{z}_{0}$ the aerodynamic roughness length taken as $0.002 \mathrm{~m}(0.2 \mathrm{~m}$ full-scale $), \kappa$ the von Karman constant equal to 0.42 and $\mathrm{z}$ the height coordinate:

$$
U(z)=\frac{u_{A B L}^{*}}{\kappa} \ln \left(\frac{z+z_{0}}{z_{0}}\right)
$$

The turbulent kinetic energy profile was calculated as in Eq. 5, where $I_{u}$ is the measured longitudinal turbulence intensity, and the turbulence dissipation rate $\varepsilon$ was calculated as in Eq. 6.

$$
\begin{aligned}
& k(z)=\left(I_{u}(z) U(z)\right)^{2} \\
& \varepsilon(z)=\frac{u_{A B L}^{* 3}}{\kappa\left(z+z_{0}\right)}
\end{aligned}
$$

The resulting vertical profiles are shown in Fig. 6. For the ground plane, the standard wall functions by Launder and Spalding [84] with the sand-grain based roughness modification by Cebeci and Bradshaw [85] were used. The equivalent sand-grain roughness height of the ground and building surfaces was taken as zero. Horizontal homogeneity of the approach-flow profiles was tested in an empty computational domain, as recommended by Blocken et al. [44,81]. The vertical profiles at the position of the first building in the empty domain are compared to the inlet profiles in Fig. 6, indicating only limited streamwise gradients. Note that two velocity profiles were scaled with the same $\mathrm{U}_{\text {ref }}$, i.e. that of the inlet profile. At the outlet of the domain, zero static gauge pressure was imposed. 
At the top and lateral sides of the domain symmetry boundary conditions were defined. The 3D steady RANS equations for incompressible and isothermal flow were solved in combination with the standard $k-\varepsilon$ turbulence model [86] but also the realizable k- $\varepsilon$ model [87] and the Renormalization Group RNG k- $\varepsilon$ model [88] were tested, as reported in Sect. 6.2. The SIMPLE algorithm was used for pressure-velocity coupling, pressure interpolation was second order and second-order discretization schemes were used for both the convection terms and the viscous terms of the governing equations. Convergence was considered to be achieved when all scaled residuals leveled off.

Following the solution of the wind flow, the local mean age of air was estimated by solving the transport equation for a passive tracer gas with a homogeneous emission rate of $10^{-6} \mathrm{~kg} / \mathrm{m}^{3} \mathrm{~s}$ in the entire computational domain. The turbulent mass fluxes were obtained using the standard gradient-diffusion hypothesis, in which the turbulent diffusivity was determined from the turbulent viscosity assuming a commonly used value for the turbulent Schmidt number, i.e. $0.7[6,7,89]$. Second-order discretization was used for the convection and diffusion terms of the passive scalar transport equation.

\section{CFD simulations: results}

\subsection{Grid-sensitivity study}

Three grids were created for case VS-B18 (scaled 1:100) by refining and coarsening the basic grid by about a factor $2^{(1 / 3)}$ in every direction, yielding a global factor 2 . The total number of cells was 846,544 for the coarse, $1,596,048$ for the basic and 3,290,148 for the fine grid. For uniform reporting of the grid-convergence study and for an estimation of the grid-induced discretization error, the Grid Convergence Index (GCI) proposed by Roache [91,92] was adopted. Fig. 7a shows the streamwise wind speed along a vertical line in front of the building at position $\mathrm{P}$ obtained with the three grids, while Fig. $7 \mathrm{~b}$ shows the pressure coefficient $\mathrm{C}_{\mathrm{p}}$ along the centerline at the windward facade of the central building obtained with the three grids. Fig. 7c shows the grid-induced error band calculated with the GCI for the basic grid solution. Fig. 7a shows that the grid resolution only marginally affects the streamwise wind speed in front of the building, while small differences are observed for the pressure coefficients for the upper part of the centerline (Fig. 7b). The grid-induced error band for the basic grid solution (Fig. 7c) confirms the higher grid sensitivity of the results at the upper part of the building facade. Nevertheless, based on these relatively small differences, the basic grid was retained for further analysis and the grids for the other cases were prepared with a similar grid resolution.

\subsection{Validation study}

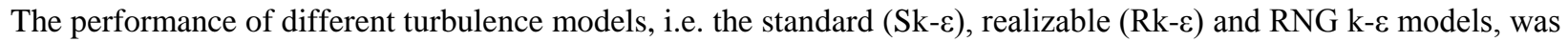
tested for VS-B18 (scale 1:100). The validation is based on pressure coefficients $\left(\mathrm{C}_{\mathrm{p}}\right)$. Although a validation study based on mean velocity and/or mean concentration would be more suitable for the present paper, such data unfortunately are not available for the cases studied by Quan et al. [76,77]. Note that also the outdoor ventilation study by Hang et al. [9] used $C_{p}$ values for validation. Fig. 8 shows the $C_{p}$ distribution along centerlines at the facade of the central building. Given the known limitations of steady RANS with linear k- $\varepsilon$ models in predicting pressures on building facades, as outlined in detail by Stathopoulos [33], the figures show an overall fair agreement between the CFD results and the wind-tunnel measurements, with the best agreement provided by the standard k- $\varepsilon$ turbulence model. A similar good agreement between measurements and results obtained with the standard k- $\varepsilon$ model has been found in previous validation studies based on velocities, as discussed in detail in Section 2. Since the Reynolds number of the flow based on the maximum building height is above 11000, the flow is considered Reynolds number independent [92] and further validation analyses are conducted using full-scale models, as reported below.

An overview of the rest of validation study for the VS-cases (full-scale) with the experimental data by Quan et al. $[76,77]$ is shown in Fig. 9 and 10. Fig. 9 compares the numerically and experimentally obtained $\mathrm{C}_{\mathrm{p}}$ distribution on the windward facade of the central building for the three cases VS-B06, VS-B12 and VS-B18. Fig. 10 compares the numerically and experimentally obtained $\mathrm{C}_{\mathrm{p}}$ distribution along the vertical centerline of the windward facade of the central building for all nine VS-cases. The results indicate that the CFD simulations are able to accurately reproduce the experimental $C_{p}$ values on the building facades especially for $\mathrm{H}=6 \mathrm{~m}$ (Fig. 10a). Average absolute deviations between computed and measured $\mathrm{C}_{\mathrm{p}}$ for this case are $0.01,0.02$, and 0.02 for plan area densities of 0.1 , 0.3 and 0.6 , respectively. For $\mathrm{H}=12$ (Fig. 10b), larger deviations are observed. The average absolute deviations for the cases with $\mathrm{H}=12 \mathrm{~m}$ are $0.10,0.04$ and 0.06 for plan area densities $0.1,0.3$ and 0.6 , respectively. Finally, the largest deviations are obtained for $\mathrm{H}=18 \mathrm{~m}$, as shown in Fig. 10c. The resulting average absolute deviations for the cases with $\mathrm{H}=18 \mathrm{~m}$ are $0.11,0.06$, and 0.17 for plan area densities $0.1,0.3$ and 0.6 , respectively. 
Given the previously demonstrated good performance of 3D steady RANS CFD simulations with k- $\varepsilon$ type models for mean wind speed in generic urban configurations (see Section 2 and Table 1) and the fairly good agreement obtained in the present validation study with the standard $k-\varepsilon$ model for pressure coefficients, it is decided to apply similar computational settings to the MS-cases in the remainder of this paper.

\subsection{MS-cases: velocity field}

Fig. 11 illustrates the wind velocity vectors at pedestrian level (1.75 $\mathrm{m}$ from the ground) for the cases MS-0 (Fig. 11 a,b) and MS-2 (Fig. $11 \mathrm{c}, \mathrm{d}$ ) with $\mathrm{H}=18 \mathrm{~m}$ and wind direction of $90^{\circ}$ and $45^{\circ}$. It can be noted that the flow patterns in Fig. 11a are consistent with the results of previous experimental [93] and numerical studies [12,66] of generic urban configurations. In particular, the following flow features identified by Princevac et al. [93] can be observed and are labeled with numbers in Fig. 12a: (1) acceleration and flow separation at the leading edge of the side building in the first row, (2) channeling effect between parallel buildings, (3) outflow in the first street canyon, (4) reattachment flow further downstream, (5) lateral inflow in the remaining rows, (6) wake region.

Fig. $12 \mathrm{~b}$ shows the same uniform configuration MS-0 but with wind direction $\theta=45^{\circ}$ (Fig. 12b). In this case, the channeling effect between parallel buildings and the lateral inflow in the downstream rows previously observed are absent. Thus, less fresh air is expected to penetrate in the area of interest, increasing the local mean age of air.

When a wider main street is introduced (configuration MS-2), the local flow patterns change significantly due to a local variation of plan area density. For the case of $\theta=90^{\circ}$ (Fig. 12c), the presence of the main street interrupts the channeling effect between buildings, but at the same time it causes a transition on the vertical plane from the skimming flow to the wake interference flow $[25,26]$ regime. Therefore, fresh air skimming over the first two rows of buildings is deflected into the main street, and this less polluted air can flow into the secondary streets downstream. The mean age of air of this configuration (MS-2, $\theta=90^{\circ}$ ) is therefore expected to be slightly lower than for the corresponding uniform configuration (MS- $0, \theta=90^{\circ}$ ).

For the wind direction $\theta=45^{\circ}$, the wind velocity along the main street increases significantly (Fig.12d). As a result, a large amount of fresh air is carried into the main street and subsequently into the narrower secondary streets and the wake low pressure zone downstream the main street helps drawing polluted air from the area of interest. The mean age of air of this configuration (MS-2, $\theta=45^{\circ}$ ) is therefore expected to be much lower than the corresponding uniform configuration (MS- $0, \theta=45^{\circ}$ ).

\subsection{Local mean age of air}

Fig. 12 summarizes the spatial-frequency distribution of the normalized local mean age of air of the MS-cases in the area of interest, at pedestrian level. This area is indicated in Fig. 4 and also at the top of Fig. 12. A systematic analysis of the results is provided below, focused on: (1) the influence of building height; (2) the influence of wind direction; (3) the influence of the main street.

1. Influence of building height. As expected, the normalized local mean age of air is increasing with the building height and has maximum values of 0.8 for $\mathrm{H}=6 \mathrm{~m}, 1.6$ for $\mathrm{H}=12 \mathrm{~m}$ and 2.2 for $\mathrm{H}=18 \mathrm{~m}$. This can be explained by considering that the plan area density $\left(\lambda_{P}\right)$ is overall quite high, ranging from 0.37 (MS-2) to 0.48 (MS-0). Grimmond and Oke [26] state that for $\lambda_{\mathrm{P}}$ higher than 0.5 the streets are not wide enough to stimulate the development of the wake interference flow regime and the main flow will eventually skim the buildings. This will yield a less efficient ventilation of the streets and this effect increases with building height, as shown in Fig. 12a, d, g.

2. Influence of wind direction. Due to this skimming flow behavior, which is especially pronounced for the uniform configuration MS-0 (i.e. the one with the highest $\left.\lambda_{\mathrm{P}}=0.48\right)$, at the pedestrian level $(1.75 \mathrm{~m})$, the influence of the main flow is very limited and the local wind flow is strongly affected by the height of the buildings and their spatial distribution. The channeling effect of the wind flow through the street canyons is then expected to be relevant when buildings are aligned with the approach-flow wind direction $\left(\theta=0^{\circ}\right.$ and $\left.\theta=90^{\circ}\right)$. The channeling effect has a positive influence on the street ventilation. This is confirmed by the results for MS- 0 and all three building heights (Fig. 12a, d, g). Indeed, for $\theta=0^{\circ}$ and $\theta=90^{\circ}$, the local mean age of air is lower than for the other wind directions due to the channeling effect. While Fig. 11 shows that the positive influence of the channeling effect is most clear for MS-0, it is to a large extent also present for MS-1 and MS-2. 
3. Influence of the main street. When a wider main street is introduced, the $\lambda_{\mathrm{p}}$ reduces locally and the local flow patterns change. Overall, Fig. 12 shows that a wider main street is beneficial for the local mean age of air of the area of interest for $\theta=22.5^{\circ}, 45^{\circ}, 67.5^{\circ}$ and $90^{\circ}$. For instance, for the cases with $\mathrm{H}=18 \mathrm{~m}$ and $\theta=45^{\circ}$ (Fig. $12 \mathrm{~g}$ i) the poorly ventilated areas with local normalized mean age of air higher than 1.2, decrease from $55 \%$ for MS-0 over $48 \%$ for MS- 1 to $20 \%$ for MS-2. Similarly, for $\theta=67.5^{\circ}$ the values decrease from $26 \%$ for MS- 0 over $18 \%$ for MS- 1 to $11 \%$ for MS- 0 . For $\theta=0^{\circ}$ however, the main street generally increases the local mean age of air in the area of interest. This difference concerning the effect of the main street as a function of wind direction is further explained below.

Fig. 13 compares the contours of the normalized local mean age of air for the cases MS- 0 and MS- 2 with H=18 m for all five wind directions. It is clear that for MS- 0 and $\theta=22.5^{\circ}, 45^{\circ}$ and $67.5^{\circ}$, high values occur at the leeward side of the buildings. For $\theta=0^{\circ}$ and $90^{\circ}$, this is less pronounced due to the channeling effect that not only acts parallel to the main wind direction but also induces flow in the perpendicular streets. For $\theta=0^{\circ}$, the presence of a wider main street yields a stronger wind flow through this street and a more effective ventilation of this street. However, it also leads to lower flow rates and therefore higher pollution concentration in the narrower streets. As a result, the local mean age of air in the area of interest increases. For the oblique wind directions $\theta=22.5^{\circ}, 45^{\circ}$ and $67.5^{\circ}$, the presence of a wider main street substantially reduces the local mean age of air in the area of interest. For these wind directions, it acts as a source of clean air that enters the narrower streets and yields a more effective ventilation there. Also for $\theta=90^{\circ}$, the local mean age of air in the area of interest generally decreases, albeit to a lesser extent than for the oblique wind directions. The decrease is mainly attributed to the reduction of the skimming flow regime in the main street, yielding more interaction between the flow above the buildings and the flow in this main street. As a result, the main street is better ventilated, and this less polluted air subsequently enters the narrow side streets in the area of interest. Indeed, comparing MS-0 and MS-2 for $\theta=90^{\circ}$ in Fig. 13, it is clear that the local mean age of air in the main street in MS-2 is clearly lower than in the corresponding narrow street in MS-0.

\section{Discussion}

The main limitations of the study are briefly mentioned:

- The study only focused on generic urban configurations composed of arrays of block-type buildings. Future work should analyze the ventilation performance for irregular building arrangements with similar and different plan and frontal area densities as analyzed in the present paper. Additionally, the study only focused on the effective local mean age of air as ventilation performance indicator. Future work should apply and compare different performance indices and discuss the suitability of different approaches.

- The validation study was mainly focused on mean pressure coefficients. While the mean pressure and mean velocity fields are closely related, a validation study based on mean velocity patterns or concentration patterns would have been more appropriate. Future work should address the establishment of high-quality experimental datasets of mean wind flow patterns for validation for building arrangements with different plan and frontal area densities.

- The present study used the 3D steady RANS equations with the standard k- $\varepsilon$ model. Although the steady RANS approach has well-known deficiencies, there are several arguments in support of its application for assessing outdoor ventilation performance in regularly spaced building arrays: (1) The present and previous validation studies indicate a satisfactory agreement with measurements; (2) Most previous studies on outdoor ventilation (see Table 1) also used this approach. (3) This approach is still the most often used in research and practice for natural ventilation studies and urban wind flow [19,20,21-23,30, 37,40,70-75,78,80].

- The results of this study are only discussed in terms of mean quantities as a consequence of the use of 3D steady RANS simulations. Future work should be performed with LES to resolve turbulence down to a certain scale and therefore reproducing the large-scale unsteady flow structures. 


\section{Conclusions}

A numerical study of the ventilation performance of generic urban configurations with equal and unequal street widths is presented in this paper by focusing on the local mean age of air at the pedestrian level. Two different sets of urban configurations composed by regular arrays of buildings with different street layouts are modeled: the VScases used for validation, and the MS-cases used to investigate the effect of a central and wider main street on the local mean age of air of the downstream area. The MS-cases have plan area densities $\lambda_{P}=0.37,0.42,0.48$ and building heights $\mathrm{H}=6 \mathrm{~m}, 12 \mathrm{~m}$ and $18 \mathrm{~m}$. The outdoor wind flow is solved with 3D steady RANS equations and standard $\mathrm{k}-\varepsilon$ turbulence model for closure, whereas the passive scalar transport equation is used to calculate the local mean age of air.

Despite the known limitation of RANS approach in predicting the pressure on the building surfaces, an overall good agreement is found between the experimental data and the numerical results of the validation cases. Some deviations are noted for the configurations with buildings $18 \mathrm{~m}$ height, in particular for plan area density of 0.6 (VSC18).

Comparing the results of the local mean age shows that the presence of the main street can be both beneficial and non-beneficial for the ventilation efficiency of the downstream area, depending on the wind direction. The tendencies are most clear for the larger building heights. For oblique wind directions, the main street acts as a sink of clean air that enters the narrower streets and yields a more effective ventilation there. For wind direction perpendicular to the main street, the wider street reduces the skimming flow regime in the main street, yielding more interaction between the flow above the buildings and the flow in this main street. As a result, the main street is better ventilated, and this less polluted air subsequently enters the narrow side streets in the downstream region. For wind flow parallel to the main street however, the higher flow rates through this street cause lower flow rates through the parallel narrower streets, and therefore lesser ventilation of these narrow streets. As a result, the local mean age of air in the downstream area increases.

\section{References}

[1] Brunekreef B, Holgate ST. Air pollution and health. The Lancet 2002;360:1233-42.

[2] Britter RE, Hanna SR. Flow and dispersion in urban areas. Annu Rev Fluid Mech 2003;35:469-96.

[3] Belcher SE. Mixing and transport in urban areas. Philos T Roy Soc A 2005;363:2947-68.

[4] Hanna SR, Brown MJ, Camelli FE, Chan ST, Coirier WJ, Hansen OR, et al. Detailed simulations of atmospheric flow and dispersion in downtown Manhattan. Bull Am Meteorol Soc 2006;87:1713-26.

[5] Di Sabatino S, Buccolieri R, Pulvirenti B, Britter R. Simulations of pollutant dispersion within idealised urban-type geometries with CFD and integral models. Atmos Environ 2007;41:8316-29.

[6] Blocken B, Stathopoulos T, Saathoff P, Wang X. Numerical evaluation of pollutant dispersion in the built environment: comparisons between models and experiments. J Wind Eng Ind Aerodyn 2008;96:1817-31.

[7] Blocken B, Tominaga Y, Stathopoulos T. CFD simulation of micro-scale pollutant dispersion in the built environment. Build Environ 2013;64:225-30.

[8] Gromke C, Buccolieri R, Di Sabatino S, Ruck B. Dispersion study in a street canyon with tree planting by means of wind tunnel and numerical investigations-evaluation of CFD data with experimental data. Atmos Environ 2008;42:8640-50.

[9] Hang J, Sandberg M, Li Y. Age of air and air exchange efficiency in idealized city models. Build Environ 2009;44:1714-23.

[10] Hang J, Sandberg M, Li Y. Effect of urban morphology on wind condition in idealized city models. Atmos Environ 2009;43:869-78.

[11] Tominaga Y, Stathopoulos T. CFD simulation of near-field pollutant dispersion in the urban environment: A review of current modeling techniques. Atmos Environ 2013;79:716-30.

[12] Buccolieri R, Sandberg M, Di Sabatino S. City breathability and its link to pollutant concentration distribution within urban-like geometries. Atmos Environ 2010;44:1894-903.

[13] Gousseau P, Blocken B, Stathopoulos T, van Heijst GJF. CFD simulation of near-field pollutant dispersion on a high-resolution grid: A case study by LES and RANS for a building group in downtown Montreal. Atmos Environ 2011;45:428-38.

[14] Kato S, Murakami S, Mochida A, Akabayashi S, Tominaga Y. Velocity-pressure field of cross ventilation with open windows analyzed by wind tunnel and numerical simulation. J Wind Eng Ind Aerodyn 1992;44:2575-86.

[15] Kato S, Murakami S, Takahashi T, Gyobu T. Chained analysis of wind tunnel test and CFD on cross ventilation of large-scale market building. J Wind Eng Ind Aerodyn 1997;67-68:573-87. 
[16] Etheridge DW, Sandberg M. Building ventilation: theory and measurement. Chichester, New York: John Wiley \& Sons; 1996.

[17] Etheridge DW. Natural ventilation of buildings. Theory, measurement and design. Wiley. 2012.

[18] Awbi HB. Ventilation of buildings. London: New York: Spon Press; 2003.

[19] Chen Q. Ventilation performance prediction for buildings: A method overview and recent applications. Build Environ 2009;44:848-58.

[20] Ramponi R, Blocken B. CFD simulation of cross-ventilation for a generic isolated building: impact of computational parameters. Build Environ 2012;53:34-48.

[21] Stathopoulos T. Pedestrian level winds and outdoor human comfort. J Wind Eng Ind Aerodyn 2006;94:76980.

[22] Mochida A, Lun IY. Prediction of wind environment and thermal comfort at pedestrian level in urban area. J Wind Eng Ind Aerodyn 2008;96:1498-527.

[23] Blocken B, Janssen WD, van Hooff T. CFD simulation for pedestrian wind comfort and wind safety in urban areas: General decision framework and case study for the Eindhoven University campus. Environ Modell Softw 2012;30:15-34.

[24] Hussain M, Lee BE. A wind tunnel study of the mean pressure forces acting on large groups of low-rise buildings. J Wind Eng Ind Aerodyn 1980;6:207-25.

[25] Oke T. Street design and urban canopy layer climate. Energy Build 1988;11:103-13.

[26] Grimmond CSB, Oke TR. Aerodynamic properties of urban areas derived from analysis of surface form. J Appl Meteorol 1999;38:1262-92.

[27] Schatzmann M, Rafailidis S, Pavageau M. Some remarks on the validation of small-scale dispersion models with field and laboratory data. J Wind Eng Ind Aerodyn 1997;67:885-93.

[28] Schatzmann M, Leitl B. Issues with validation of urban flow and dispersion CFD models. J Wind Eng Ind Aerodyn 2011;99:169-86.

[29] van Hooff T, Blocken B. Full-scale measurements of indoor environmental conditions and natural ventilation in a large semi-enclosed stadium: possibilities and limitations for CFD validation. J Wind Eng Ind Aerodyn 2012;104-106: 330-341.

[30] Van Hooff T, Blocken B. Coupled urban wind flow and indoor natural ventilation modelling on a highresolution grid: A case study for the Amsterdam ArenA stadium. Environ Modell Softw 2010;25:51-65.

[31] Blocken B. 50 years of Computational Wind Engineering: Past, present and future. J Wind Eng Ind Aerodyn 2014;129:69-102.

[32] Murakami, S. Current status and future trends in computational wind engineering. J Wind Eng Ind Aerodyn 1997;67-68: 3-34.

[33] Stathopoulos T. Computational wind engineering: Past achievements and future challenges. J Wind Eng Ind Aerodyn 1997;67:509-32.

[34] Murakami, S. Overview of turbulence models applied in CWE-1997. J Wind Eng Ind Aerodyn 1998;74-76: $1-24$.

[35] Blocken, B., Carmeliet, J. A review of wind-driven rain research in building science. J Wind Eng Ind Aerodyn 2004;92 (13):1079-1130.

[36] Meroney, R.N. Wind tunnel and numerical simulation of pollution dispersion: a hybrid approach. Paper for Invited Lecture at the Croucher Advanced Study Institute, Hong Kong University of Science and Technology, 6-10 December 2004.

[37] Blocken B, Stathopoulos T, Carmeliet J, Hensen JLM. Application of computational fluid dynamics in building performance simulation for the outdoor environment: an overview. J Building Perform Simul 2011;4:157-84.

[38] Moonen P, Defraeye T, Dorer V, Blocken B, Carmeliet J. Urban Physics: Effect of the micro-climate on comfort, health and energy demand. Frontiers of Architectural Research 2012;1:197-228.

[39] Di Sabatino S, Buccolieri R, Salizzoni P. Recent advancements in numerical modelling of flow and dispersion in urban areas: a short review. Int J Environ Pollut 2013;52(3-4):172-191.

[40] Blocken B. 2015. Computational Fluid Dynamics for Urban Physics: Importance, scales, possibilities, limitations and ten tips and tricks towards accurate and reliable simulations. Build. Environ. doi:10.1016/j.buildenv.2015.02.015

[41] Skote M, Sandberg M, Westerberg U, Claesson L, Johansson AV. Numerical and experimental studies of wind environment in an urban morphology. Atmos Environ 2005;39:6147-6158.

[42] Liu CH, Leung DYC, Barth MC. On the prediction of air and pollutant exchange rates in street canyons of different aspect ratios using large-eddy simulation. Atmos Environ 2005;39:1567-1574. 
[43] Li XX, Liu CH, Leung DYC. Development of a k-e model for the determination of air exchange rates for street canyons. Atmos Environ 2005;39:7285-7296.

[44] Blocken B, Carmeliet J, Stathopoulos T. CFD evaluation of wind speed conditions in passages between parallel buildings-effect of wall-function roughness modifications for the atmospheric boundary layer flow. $\mathrm{J}$ Wind Eng Ind Aerodyn 2007;95:941-62.

[45] Bady M, Kato S, Huang H. Towards the application of indoor ventilation efficiency indices to evaluate the air quality of urban areas. Build Environ 2008;43:1991-2004.

[46] Blocken B, Moonen P, Stathopoulos T, Carmeliet J. Numerical study on the existence of the Venturi effect in passages between perpendicular buildings. J Eng Mech - ASCE 2008;134:1021-8.

[47] Cheng WC, Liu CH, Leung DYC. Computational formulation for the evaluation of street canyon ventilation and pollutant removal performance. Atmos Environ 2008; 42:9041-9051.

[48] Bu Z, Kato S, Ishida Y, Huang $\mathrm{H}$. New criteria for assessing local wind environment at pedestrian level based on exceedance probability analysis. Build Environ 2009;44:1501-8.

[49] Hang J, Sandberg M, Li Y, Claesson L. Flow mechanisms and flow capacity in idealized long-street city models. Build Environ 2010a;45:1042-1053.

[50] Hang J, Li Y, Sandberg M, Claesson L. Wind conditions and ventilation in high-rise long street models. 2010b; 45: 1353-1365.

[51] Hang J, Li Y. Ventilation strategy and air change rates in idealized high-rise compact urban areas. Build Environ 2010a; 45:2754-2767.

[52] Hang J, Li Y. Wind conditions in idealized building clusters: macroscopic simulations using a porous turbulence model. Bound-Layer Meteorol. 2010b; 136:129-159.

[53] Moonen P, Dorer V, Carmeliet J. Evaluation of the ventilation potential of courtyards and urban street canyons using RANS and LES. J Wind Eng Ind Aerodyn 2011; 99:414-423.

[54] Hang J, Li Y, Sandberg M, Buccolieri R, Di Sabatino S. The influence of building height variability on pollutant dispersion and pedestrian ventilation in idealized high-rise urban areas. Build Environ 2012a; 56:346-360.

[55] Hang J, Li Y, Buccolieri R, Sandberg M, Di Sabatino S. On the contribution of mean flow and turbulence to city breathability: The case of long streets with tall buildings. Sci Total Environ 2012b; 416:362-373.

[56] Hang J, Luo Z, Sandberg M, Gong J. Natural ventilation assessment in typical open and semi-open urban environments under various wind conditions. Build Environ 2013;70:318-333.

[57] Lin M, Hang J, Li Y, Luo Z, Sandberg M. Quantitative ventilation assessments of idealized urban canopy laer with various urban layouts and the same building packing density. Build Environ 2014;79:152-167.

[58] Sandberg M. Ventilation effectiveness and purging flow rate-A review. International symposium on room air convection and ventilation effectiveness, 1992.

[59] Peng S-H, Holmberg S, Davidson L. On the assessment of ventilation performance with the aid of numerical simulations. Build Environ 1997;32:497-508.

[60] Kato S, Ito K, Murakami S. Analysis of visitation frequency through particle tracking method based on LES and model experiment. Indoor Air 2003;13:182-93.

[61] Niachou K, Hassid S, Santamouris M, Livada I. Experimental performance investigation of natural, mechanical and hybrid ventilation in urban environment. Build Environ 2008;43:1373-82.

[62] Sandberg M, Lundström H, Nilsson HO, Stymne H. Experimental methods in Ventilation. Advances in Building Energy Research 2008;2:159-210.

[63] Wang A, Zhang Y, Sun Y, Wang X. Experimental study of ventilation effectiveness and air velocity distribution in an aircraft cabin mockup. Build Environ 2008;43:337-43.

[64] Bentham T, Britter R. Spatially averaged flow within obstacle arrays. Atmos Environ, 2003; 37(15): 2037-2043.

[65] Neophytou MK-A, Britter RE. Modelling the wind flow in complex urban topographies: a ComputationalFluid-Dynamics simulation of the central London area. Proceedings of the Fifth GRACM International Congress on Computational Mechanics, Limassol, Cyprus, 29 June-1 July, 2005; 2005.

[66] Tominaga Y. Visualization of city breathability based on CFD technique: case study for urban blocks in Niigata City. J Vis, 2012; 15.3: 269-276.

[67] Panagiotou I, Neophytou M, Hamlyn D, Britter R. City breathability as quantified by the exchange velocity and its spatial variation in real inhomogeneous urban geometries: An example from central London urban area. Sci Total Environ 2013; 442: 466-477. 
[68] Neophytou M, Markides CN, Fokaides PA. An experimental study of the flow through and over two dimensional rectangular roughness elements: Deductions for urban boundary layer parameterizations and exchange processes. Phys Fluids 2014; 26.8: 086603.

[69] Tominaga Y, Mochida A, Murakami S, Sawaki S. Comparison of various revised k-e models and LES applied to flow around a high-rise building model with 1:1:2 shape placed within the surface boundary layer. J Wind Eng Ind Aerodyn 2008;96(4):389-411.

[70] Yoshie R, Mochida A, Tominaga Y, Kataoka H, Harimoto K, Nozu T, et al. Cooperative project for CFD prediction of pedestrian wind environment in the Architectural Institute of Japan. J Wind Eng Ind Aerodyn 2007;95:1551-78.

[71] Janssen WD, Blocken B, van Hooff T. Pedestrian wind comfort around buildings: Comparison of wind comfort criteria based on whole-flow field data for a complex case study. Build Environ 2013;59:547-62.

[72] van Hooff T, Blocken B. On the effect of wind direction and urban surroundings on natural ventilation of a large semi-enclosed stadium. Comput Fluids 2010;39:1146-1155.

[73] Montazeri H, Blocken B, Janssen WD, van Hooff T. CFD evaluation of new second-skin facade concept for wind comfort on building balconies: Case-study for the Park Tower in Antwerp. Build Environ 2013;68:179192.

[74] Gromke CB, Blocken B, Janssen WD, Merema B, van Hooff T, Timmermans HJP. CFD analysis of transpirational cooling by vegetation: Case study for specific meteorological conditions during a heat wave in Arnhem, Netherlands. Build Environ 2015; 83: 11-26.

[75] Toparlar Y, Blocken B, Vos P, van Heijst GJF, Janssen WD, van Hooff T, Montazeri H, Timmermans HJP. 2015. CFD simulation and validation of urban microclimate: A case study for Bergpolder Zuid, Rotterdam. Build Environ 2015; 83: 79-90.

[76] Quan Y, Tamura Y, Matsui M, Cao S, Yoshida A, Xu S. Interference effect of a surrounding building group on wind loads on flat roof of low-rise building: Part I, Distribution of local wind pressure coefficient. Wind Engineers, JAWE 2007;32:211-2.

[77] Quan Y, Tamura Y, Matsui M, Cao S, Yoshida A, Xu S. Interference effect of a surrounding building group on wind loads on flat roof of low-rise building: Part II, Interference factor of worst extreme local and areaaveraged suction pressure coefficients. Wind Engineers, JAWE 2007;32:213-4.

[78] Tominaga Y, Mochida A, Yoshie R, Kataoka H, Nozu T, Yoshikawa M, et al. AIJ guidelines for practical applications of CFD to pedestrian wind environment around buildings. J Wind Eng Ind Aerodyn 2008;96:1749-61.

[79] Architectural Institute of Japan (AIJ). Recommendations for loads on buildings 2004.

[80] Franke J, Hellsten A, Schlünzen H, Carissimo B. Best practice guideline for the CFD simulation of flows in the urban environment. COST action, vol. 732, 2007.

[81] Blocken B, Stathopoulos T, Carmeliet J. CFD simulation of the atmospheric boundary layer: wall function problems. Atmos Environ 2007;41:238-52.

[82] Casey M, Wintergerste T. ERCOFTAC special interest group on quality and trust in industrial CFD: best practices guidelines. 2000.

[83] Tucker PG, Mosquera A. Introduction to grid and mesh generation for CFD. NAFEMS; 2001.

[84] Launder BE, Spalding DB. The numerical computation of turbulent flows. Comput Method Appl M 1974;3:269-89.

[85] Cebeci T, Bradshaw P. Momentum transfer in boundary layers. New York, McGraw-Hill Book Co. Washington, DC: Hemisphere Publishing Corp; 1977.

[86] Jones W, Launder B. The prediction of laminarization with a two-equation model of turbulence. Int J Heat Mass Transfer 1972;15:301-14.

[87] Shih TH, Liou WW, Shabbir A, Yang Z, Zhu J. A new k- $\varepsilon$ eddy viscosity model for high Reynolds number turbulent flows. Comput Fluids 1995;24:227-38.

[88] Yakhot V, Orszag SA, Thangam S, Gatski TB, Speziale CG. Development of turbulence models for shear flows by a double expansion technique. Phys Fluids 1992;4:1510-20.

[89] Tominaga, Y., Stathopoulos, T. Turbulent Schmidt numbers for CFD analysis with various types of flowfield. Atmos Environ 2007;41 (37):8091-8099.

[90] Roache PJ. Perspective: a method for uniform reporting of grid refinement studies. J Fluids Eng 1994;116:405-405.

[91] Roache PJ. Quantification of uncertainty in computational fluid dynamics. Annu Rev Fluid Mech 1997;29:123-60. 
[92] Snyder WH. Similarity criteria for the application of fluid models to the study of air pollution meteorology. Bound-Layer Meteorol 1972;3:113-34.

[93] Princevac M, Baik J J, Li X, Pan H, Park S B. Lateral channeling within rectangular arrays of cubical obstacles. J Wind Eng Ind Aerod 2010; 98(8): 377-385. 
LIST OF TABLES 
Table 1. Overview of CFD studies on urban wind flow and outdoor ventilation of simplified urban configurations, including study of integral parameters for ventilation performance.

\begin{tabular}{|c|c|c|c|c|c|c|c|c|}
\hline Authors (year) & Ref. & $\begin{array}{l}\text { Study } \\
\text { type }\end{array}$ & Configuration & $\begin{array}{l}\text { Turbulence } \\
\text { modelling }\end{array}$ & $\begin{array}{l}\text { Scalar } \\
\text { transport }\end{array}$ & $\begin{array}{l}\text { Evaluation } \\
\text { parameter }\end{array}$ & Validation & Sensitivity analysis \\
\hline $\begin{array}{l}\text { Skote et al. } \\
(2005)\end{array}$ & {$[41]$} & Generic & $\begin{array}{l}\text { 3D/Circular } \\
\text { block with } 2 \text { or } \\
4 \text { sectors }\end{array}$ & $\begin{array}{l}\text { Steady RANS } \\
(\mathrm{SSTKO})\end{array}$ & $\mathrm{N}$ & $\mathrm{Q}$ & $\mathrm{Y}(\mathrm{WT})$ & $\begin{array}{l}\text { Gridres, Wdir, } \\
\text { Street.num. }\end{array}$ \\
\hline Liu et al. (2005) & {$[42]$} & Generic & $\begin{array}{l}\text { 3D/Street } \\
\text { canyon }\end{array}$ & LES (Dyn.) & $\begin{array}{l}\text { Y (Pass., } \\
\text { Ground line } \\
\text { source) }\end{array}$ & $\tau_{\mathrm{p}}, \mathrm{ACH}, \mathrm{PCH}$ & $\mathrm{Y}(\mathrm{WT})$ & Canyon AR \\
\hline Li et al. (2005) & {$[43]$} & Generic & $\begin{array}{l}\text { 2D/Street } \\
\text { canyon }\end{array}$ & $\begin{array}{l}\text { Steady RANS } \\
\text { (RNG) }\end{array}$ & $\mathrm{N}$ & $\mathrm{ACH}$ & $\mathrm{Y}(\mathrm{WT})$ & Canyon AR \\
\hline $\begin{array}{l}\text { Blocken et al. } \\
(2007)\end{array}$ & {$[44]$} & Generic & $\begin{array}{l}3 \mathrm{D} / 2 \text { parallel } \\
\text { buildings }\end{array}$ & $\begin{array}{l}\text { Steady RANS } \\
\text { (RKE) }\end{array}$ & $\mathrm{N}$ & Q & $\mathrm{Y}(\mathrm{WT})$ & $\begin{array}{l}\text { Gridres, Buildgeom, } \\
\text { Street width }\end{array}$ \\
\hline $\begin{array}{l}\text { Bady et al. } \\
(2008)\end{array}$ & {$[45]$} & Generic & $\begin{array}{l}3 \mathrm{D} / 2 \text { buildings, } \\
\text { aligned and } \\
\text { staggered array }\end{array}$ & $\begin{array}{l}\text { Steady RANS } \\
\text { (SKE) }\end{array}$ & $\begin{array}{l}\text { Y (Pass., } \\
\text { Hom.em.) }\end{array}$ & PFR, VF, TP & $\mathrm{N}$ & $\begin{array}{l}\text { Buildgeom, Street } \\
\text { width, Wdir, } \\
\text { Dom.height }\end{array}$ \\
\hline $\begin{array}{l}\text { Blocken et al. } \\
(2008)\end{array}$ & {$[46]$} & Generic & $\begin{array}{l}3 \mathrm{D} / 2 \text { buildings } \\
\text { in } \mathrm{V} \text { - } \\
\text { arrangement }\end{array}$ & $\begin{array}{l}\text { Steady RANS } \\
\text { (RKE) }\end{array}$ & $\mathrm{N}$ & Q & Y (WT) & $\begin{array}{l}\text { Gridres, Wdir, Street } \\
\text { width }\end{array}$ \\
\hline $\begin{array}{l}\text { Cheng et al. } \\
(2008)\end{array}$ & [47] & Generic & $\begin{array}{l}2 \mathrm{D} / \text { Street } \\
\text { canyon }\end{array}$ & $\begin{array}{l}\text { Steady RANS } \\
(\mathrm{RNG})\end{array}$ & $\begin{array}{l}\text { Y (pass., } \\
\text { ground-level } \\
\text { source) }{ }^{a}\end{array}$ & $\tau_{\mathrm{p}}, \mathrm{ACH}, \mathrm{PCH}$ & $\mathrm{Y}(\mathrm{WT})$ & $\begin{array}{l}\text { Gridres, Canyon AR, } \\
\text { Discr.ord. }\end{array}$ \\
\hline Bu et al. (2009) & {$[48]$} & Generic & $\begin{array}{l}\text { 3D/Street } \\
\text { canyon }\end{array}$ & $\begin{array}{l}\text { Steady RANS } \\
\text { (SKE) }\end{array}$ & $\begin{array}{l}\text { Y (Pass., } \\
\text { Hom.em.) }\end{array}$ & $\mathrm{ACH}$ & $\mathrm{N}$ & Wdir, Canyon AR \\
\hline $\begin{array}{l}\text { Hang et al. } \\
\text { (2009a) }\end{array}$ & [9] & Generic & $\begin{array}{l}\text { 3D/Circular, } \\
\text { square, rect. city } \\
\text { model }\end{array}$ & $\begin{array}{l}\text { Steady RANS } \\
\text { (SKE, RNG) }\end{array}$ & $\mathrm{N}$ & Q & Y (WT) & $\begin{array}{l}\text { Gridres, Citygeom, } \\
\text { Street.num, Wdir }\end{array}$ \\
\hline $\begin{array}{l}\text { Hang et al. } \\
(2009 b)\end{array}$ & {$[10]$} & Generic & $\begin{array}{l}\text { 3D/Circular, } \\
\text { square, rect. city } \\
\text { model }\end{array}$ & $\begin{array}{l}\text { Steady RANS } \\
\text { (SKE, RNG) }\end{array}$ & $\begin{array}{l}\text { Y (Pass., } \\
\text { Hom.em.) }\end{array}$ & $\mathrm{Q}, \varepsilon_{\mathrm{a}}, \tau_{\mathrm{p}}$ & $\mathrm{Y}(\mathrm{WT})^{\mathrm{b}}$ & $\begin{array}{l}\text { Citygeom, Street.num, } \\
\text { Wdir }\end{array}$ \\
\hline $\begin{array}{l}\text { Hang et al. } \\
(2010 a)\end{array}$ & [49] & Generic & $\begin{array}{l}\text { 3D/Long street } \\
\text { models }\end{array}$ & $\begin{array}{l}\text { Steady RANS } \\
\text { (SKE) }\end{array}$ & $\mathrm{N}$ & $\mathrm{Q}, \mathrm{E}$ & $\mathrm{Y}(\mathrm{WT})$ & $\begin{array}{l}\text { Street width, Street } \\
\text { length }\end{array}$ \\
\hline $\begin{array}{l}\text { Hang et al. } \\
(2010 b)\end{array}$ & {$[50]$} & Generic & $\begin{array}{l}3 \mathrm{D} / \text { Long street } \\
\text { models }\end{array}$ & $\begin{array}{l}\text { Steady RANS } \\
\text { (SKE, RNG) }\end{array}$ & $\mathrm{N}$ & $\mathrm{Q}, \mathrm{ACH}$ & $\mathrm{Y}(\mathrm{WT})$ & $\begin{array}{l}\text { Buildheight, Street } \\
\text { width }\end{array}$ \\
\hline
\end{tabular}




\begin{tabular}{|c|c|c|c|c|c|c|c|c|}
\hline $\begin{array}{l}\text { Hang \& Li } \\
(2010 \mathrm{a})\end{array}$ & [51] & Generic & $\begin{array}{l}\text { 3D/Aligned } \\
\text { array }\end{array}$ & $\begin{array}{l}\text { Steady RANS } \\
\text { (SKE) }\end{array}$ & $\mathrm{N}$ & $\mathrm{Q}, \mathrm{ACH}$ & $\mathrm{Y}(\mathrm{WT})$ & $\begin{array}{l}\text { Gridres, Buildgeom, } \\
\lambda_{p}, \text { Wdir }\end{array}$ \\
\hline $\begin{array}{l}\text { Hang \& Li } \\
(2010 \mathrm{~b})\end{array}$ & [52] & Generic & $\begin{array}{l}\text { 3D/Aligned } \\
\text { arrays of cubes }\end{array}$ & $\begin{array}{l}\text { Steady RANS } \\
\text { (SKE) }\end{array}$ & $\mathrm{N}$ & $\mathrm{Q}, \mathrm{ACH}$ & $\mathrm{Y}(\mathrm{WT})$ & Num of rows, Gridres \\
\hline $\begin{array}{l}\text { Buccolieri et al. } \\
(2010)\end{array}$ & [12] & Generic & $\begin{array}{l}\text { 3D/Aligned } \\
\text { array of cubes }\end{array}$ & $\begin{array}{l}\text { Steady RANS } \\
\text { (SKE) }\end{array}$ & $\begin{array}{l}\text { Y (Pass., } \\
\text { Hom.em.) }\end{array}$ & $\mathrm{Q}, \tau_{\mathrm{p}}$ & $\mathrm{Y}(\mathrm{WT})$ & Gridres, $\lambda_{\mathrm{p}}$ \\
\hline $\begin{array}{l}\text { Moonen et al. } \\
\text { (2011) }\end{array}$ & [53] & Generic & 3D/Courtyard & $\begin{array}{l}\text { Steady RANS } \\
\text { (RKE), LES (Dyn.) }\end{array}$ & $\mathrm{N}$ & Q & $\mathrm{N}$ & Court.length, Wdir. \\
\hline $\begin{array}{l}\text { Hang et al. } \\
\text { (2012a) }\end{array}$ & [54] & Generic & $\begin{array}{l}3 \mathrm{D} / \text { Aligned } \\
\text { array }\end{array}$ & $\begin{array}{l}\text { Steady RANS } \\
\text { (SKE, RNG) }\end{array}$ & $\begin{array}{l}\text { Y (Pass., } \\
\text { Hom.em.) }\end{array}$ & PFR & $\mathrm{Y}(\mathrm{WT})$ & $\begin{array}{l}\text { Buildheight, } \\
\text { Num.rows.array }\end{array}$ \\
\hline $\begin{array}{l}\text { Hang et al. } \\
(2012 b)\end{array}$ & [55] & Generic & $\begin{array}{l}\text { 3D/Long street } \\
\text { models }\end{array}$ & $\begin{array}{l}\text { Steady RANS } \\
\text { (SKE, RNG) }\end{array}$ & $\begin{array}{l}\text { Y (Pass., } \\
\text { Hom.em.) }\end{array}$ & $\tau_{\mathrm{p}},<\tau_{\mathrm{p}}>$ & $\mathrm{Y}(\mathrm{WT})$ & $\begin{array}{l}\text { Gridres, Buildheight, } \\
\text { Street length }\end{array}$ \\
\hline $\begin{array}{l}\text { Hang et al. } \\
\text { (2013) }\end{array}$ & [56] & Generic & $\begin{array}{l}\text { 3D/aligned } \\
\text { arrays }\end{array}$ & $\begin{array}{l}\text { Steady RANS } \\
\text { (SKE, RNG, RKE, } \\
\text { RSM) }\end{array}$ & $\begin{array}{l}\text { Y (Pass., } \\
\text { Hom.em.) }\end{array}$ & $\mathrm{Q}, \tau_{\mathrm{p}}, \mathrm{PFR}$ & $\mathrm{Y}(\mathrm{WT})$ & Street roof geom. \\
\hline Lin et al. (2014) & [57] & Generic & $\begin{array}{l}\text { 3D/Aligned \& } \\
\text { staggered arrays }\end{array}$ & $\begin{array}{l}\text { Steady RANS } \\
\text { (SKE) }\end{array}$ & $\begin{array}{l}\text { Y (Pass., } \\
\text { Hom.em.) }\end{array}$ & $\mathrm{Q}, \mathrm{ACH}, \mathrm{PFR}$ & $\mathrm{Y}(\mathrm{WT})$ & $\begin{array}{l}\text { Turb.mod, } \\
\text { Buildheight, Array } \\
\text { size, Wdir. }\end{array}$ \\
\hline
\end{tabular}

Table legend: rect. $=$ rectangular; RANS $=$ Reynolds-averaged Navier-Stokes; SSTKO $=$ SST k- $\omega$ model; SKE $=$ standard $\mathrm{k}-\varepsilon$ model; RNG $=$ Renormalization Group k- $\varepsilon$ model; RLZ = realizable k- $\varepsilon$ model; RSM = Reynolds stress model; LES = Large eddy simulation; Dyn. = dynamic Smagorinsky-Lilly SGS model; Y $=$ yes; $\mathrm{N}=$ no; Pass. = passive; Hom.em. = homogeneous emission method; $\mathrm{Q}=$ flow rate $; \tau_{\mathrm{p}}=$ effective local mean age of air; $\mathrm{ACH}=$ air change rate; $\mathrm{PRF}=$ purging flow rate; $\mathrm{VF}=$ visitation frequency; $\mathrm{TP}=$ residence time; $\mathrm{PCH}=$ pollutant exchange rate; $\varepsilon_{\mathrm{a}}=$ air exchange efficiency; $\mathrm{E}=$ total energy density; $\left\langle\tau_{\mathrm{p}}\right\rangle=$ spatially averaged mean age of air; $\mathrm{WT}=$ wind tunnel; Gridres. = grid resolution; $\mathrm{Wdir} .=$ wind direction; Street.num. $=$ number of streets; Canyon AR = canyon aspect ratio; Buildgeom. = building geometry; Dom.height $=$ domain height; Discr.ord. = order of discretization scheme; Citygeom. = city geometry; Buildheight $=$ building height; $\lambda_{\mathrm{p}}=$ packing area density; Num. of rows = number of rows; Court.length = courtyard length; Num.rows.array. = number of rows in array; Street roof geom. $=$ street roof geometry; Turb.mod. $=$ Turbulence model;

(a) Uniform emission over ground surface; $\left({ }^{b}\right)$ Validation reported in previous study [9]. 
Table 2. Typical street configurations and resulting width of the streets for the MS-cases

\begin{tabular}{|c|c|c|c|c|}
\hline \multicolumn{2}{|l|}{ Street elements } & \multicolumn{3}{|c|}{ MS-cases } \\
\hline Description & Width [m] & MS-0 & MS-1 & MS-2 \\
\hline Private garden & 3.0 & & & $\mathrm{x}$ \\
\hline Sidewalk & 1.5 & $\mathrm{x}$ & $\mathrm{x}$ & $\mathrm{x}$ \\
\hline Parking & 2.0 & & & $\mathrm{x}$ \\
\hline Cycle lane & 2.0 & & $\mathrm{x}$ & $\mathrm{x}$ \\
\hline Road & 3.5 & & $\mathrm{x}$ & $\mathrm{x}$ \\
\hline Road & 3.5 & $\mathrm{x}$ & $\mathrm{x}$ & $\mathrm{x}$ \\
\hline Cycle lane & 2.0 & & $\mathrm{X}$ & $\mathrm{x}$ \\
\hline Parking & 2.0 & $\mathrm{x}$ & $\mathrm{x}$ & $\mathrm{x}$ \\
\hline Sidewalk & 1.5 & $\mathrm{x}$ & $\mathrm{x}$ & $\mathrm{x}$ \\
\hline Private garden & 3.0 & & & $\mathrm{x}$ \\
\hline Main street width $\mathrm{W}_{\mathrm{S}}[\mathrm{m}]$ & & 8.5 & 16.0 & 24.0 \\
\hline Secondary street width [m] & & 8.5 & 8.5 & 8.5 \\
\hline Plan area density [-] & & 0.48 & 0.42 & 0.37 \\
\hline
\end{tabular}

Table 3. Total number of computational cells for VS-cases and MS-cases

\begin{tabular}{ccccccc}
\hline & \multicolumn{3}{c}{ VS-cases } & \multicolumn{3}{c}{ MS-cases } \\
& VS-A & VS-B & VS-C & MS-0 & MS-1 & MS-2 \\
\hline $\mathrm{H}=6 \mathrm{~m}$ & 682,128 & $1,514,520$ & $1,360,332$ & $1,459,236$ & $1,459,236$ & $1,496,110$ \\
$\mathrm{H}=12 \mathrm{~m}$ & 677,376 & $1,555,284$ & $1,340,810$ & $1,488,298$ & $1,488,298$ & $1,496,110$ \\
$\mathrm{H}=18 \mathrm{~m}$ & 797,008 & $1,596,048$ & $1,320,506$ & $1,517,360$ & $1,517,360$ & $1,525,424$ \\
\hline
\end{tabular}




\section{FIGURES}

Plan area density: $\lambda_{P}=A_{P} / A_{L}$

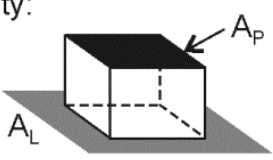

Frontal area density:

$\lambda_{F}=A_{F} / A_{L}$

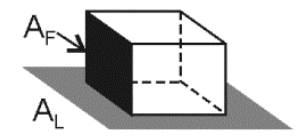

Figure 1. Definition of plan area density $\left(\lambda_{\mathrm{P}}\right)$ and frontal area density $\left(\lambda_{\mathrm{F}}\right)$

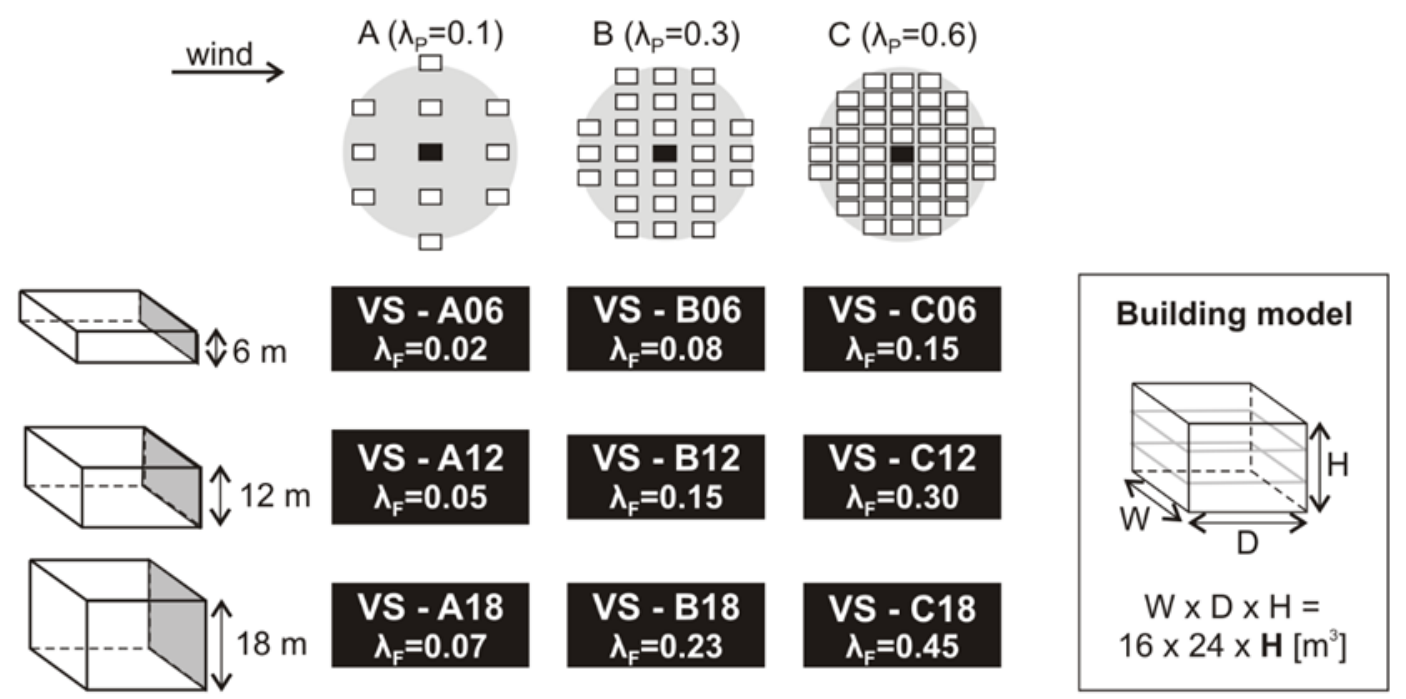

Figure 2. Definition of the VS-cases by varying the plan area density $\left(\lambda_{\mathrm{P}}\right)$ and the building height (left); size of the building models in full-scale (right). 
(a)
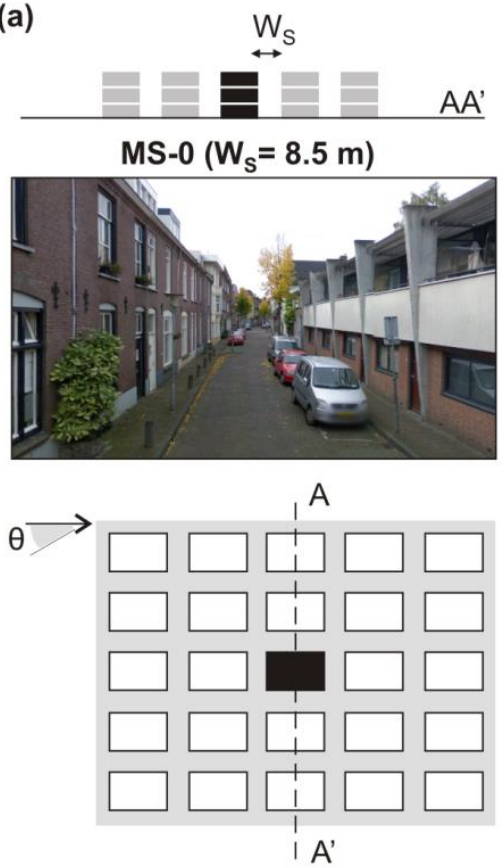

(b)

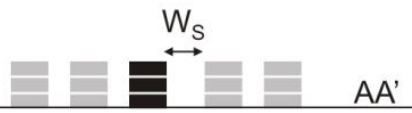

MS-1 $\left(W_{\mathrm{s}}=16 \mathrm{~m}\right)$

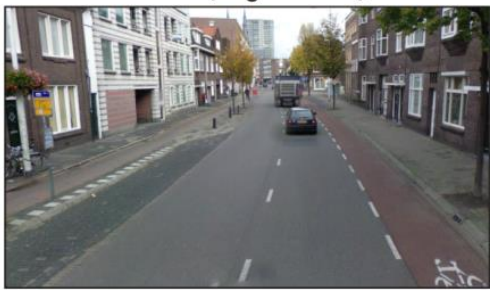

A

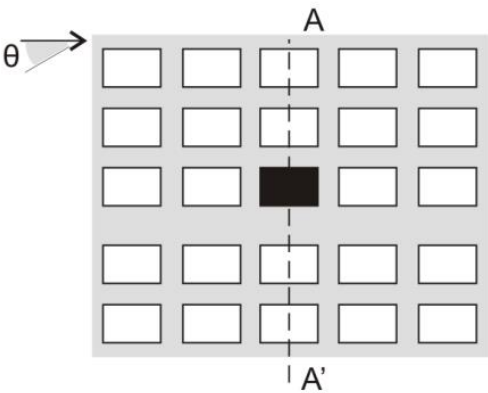

(c)
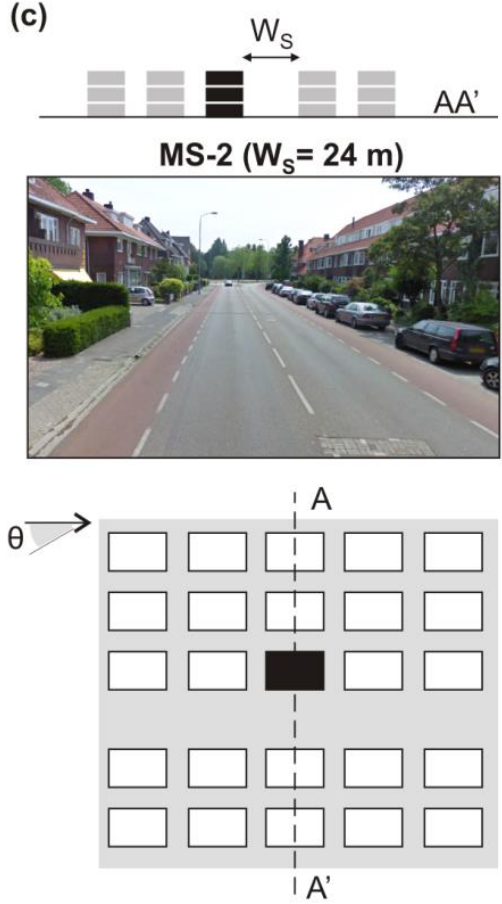

Figure 3. Definition of the MS-cases with main central street width of $8.5 \mathrm{~m}$ (MS-0), $16 \mathrm{~m}$ (MS-1) and $24 \mathrm{~m}$ (MS-2), and comparison with streets of the city of Eindhoven (The Netherlands) (source: Google street view)

(a)

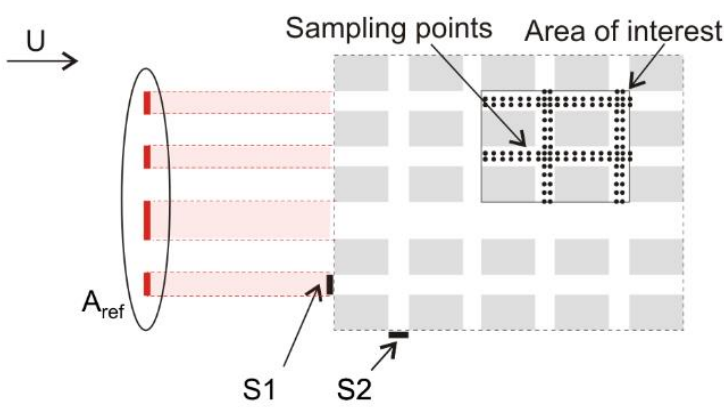

(b)

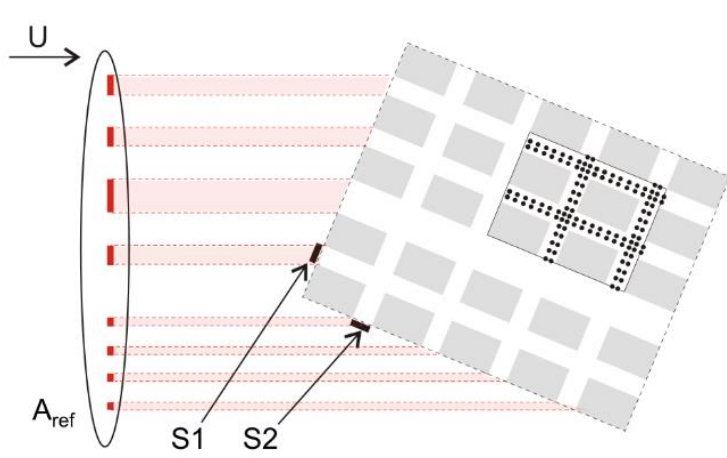

Figure 4. Definition of the local mean age of air for the cases with wind directions $0^{\circ}$ and $22.5^{\circ}$ (e.g.): inlet street openings S1 and S2 used to calculate the initial values of the local mean age of air in the urban configuration; distribution of sampling points within the area of interest used to calculate the spatial-frequency distribution of the normalized local mean age of air; inlet street opening areas $\left(\mathrm{A}_{\text {ref }}\right)$ used to calculate the volume flow rate $\mathrm{Q}_{\text {ref. }}$. 
(a) Central

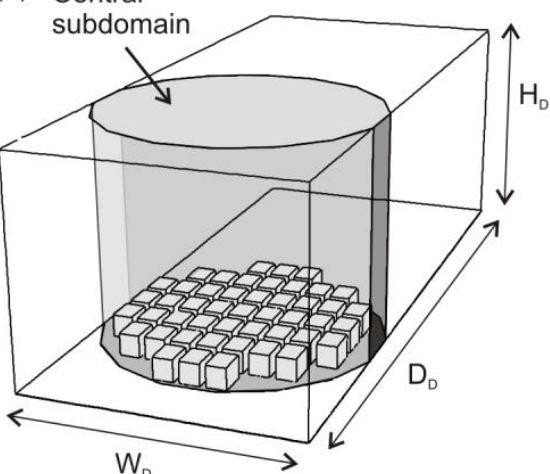

(b)

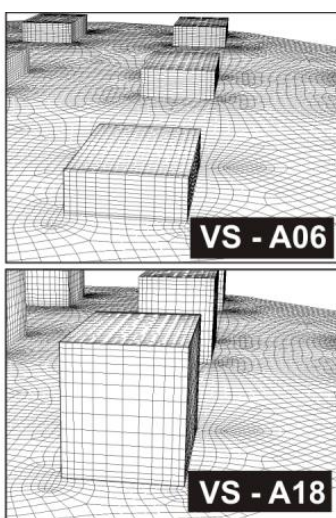

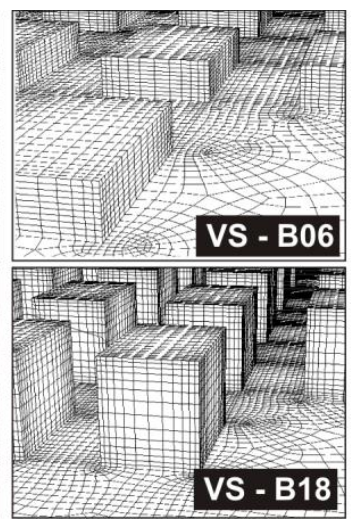

Figure 5. (a) Computational domain as composed by a central subdomain and an external subdomain. (b) Part of the computational grid on the buildings and ground surface for VS-A06, VS-B06, VS-C06 (top), and VS-A18, VS-B18, VS-C18 (bottom) (codes according to Fig. 2).

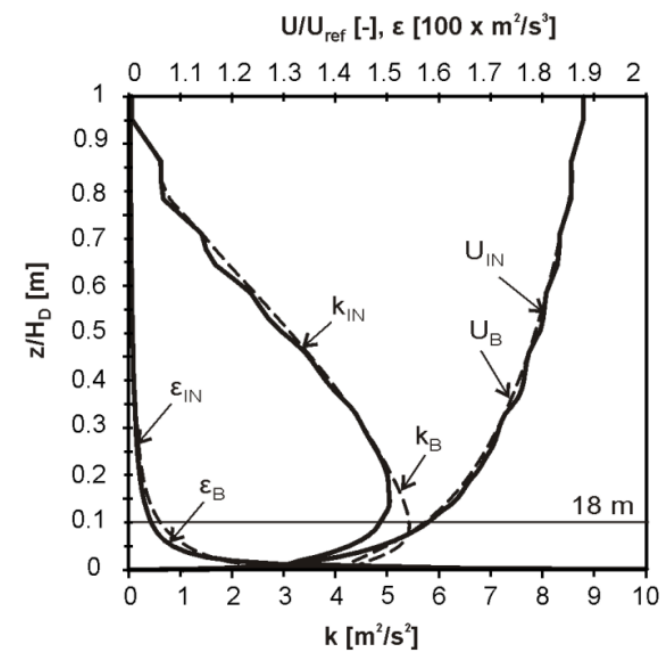

Figure 6. Vertical profiles of dimensionless mean speed $\mathrm{U} / \mathrm{U}_{\text {ref, }}$, turbulent kinetic energy $\mathrm{k}$ and turbulence dissipation rate $\varepsilon$ at the inlet of the domain $\left(\mathrm{U}_{\mathrm{IN}}, \mathrm{k}_{\mathrm{IN}}, \varepsilon_{\mathrm{IN}}\right)$ and at the position of the first building in the empty computational domain $\left(\mathrm{U}_{\mathrm{B}}, \mathrm{k}_{\mathrm{B}}, \varepsilon_{\mathrm{B}}\right)$. 
(a)

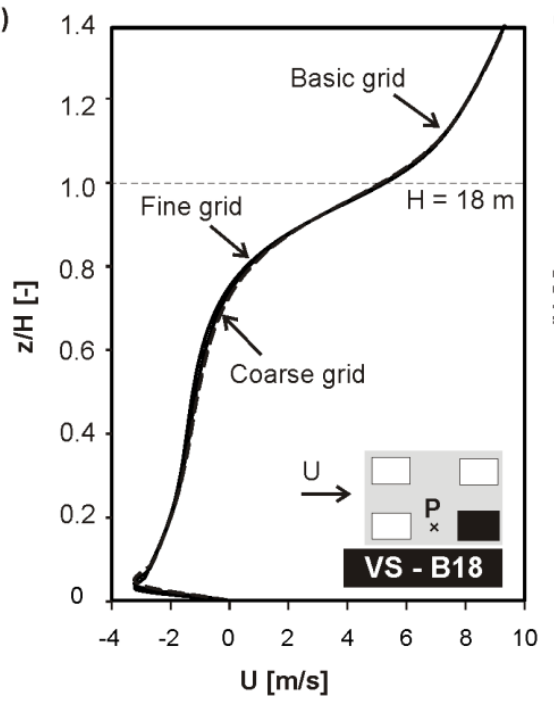

(b)

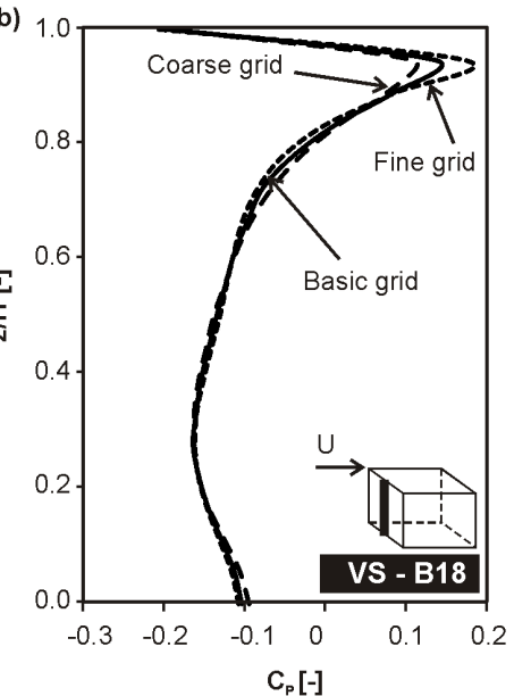

(c)

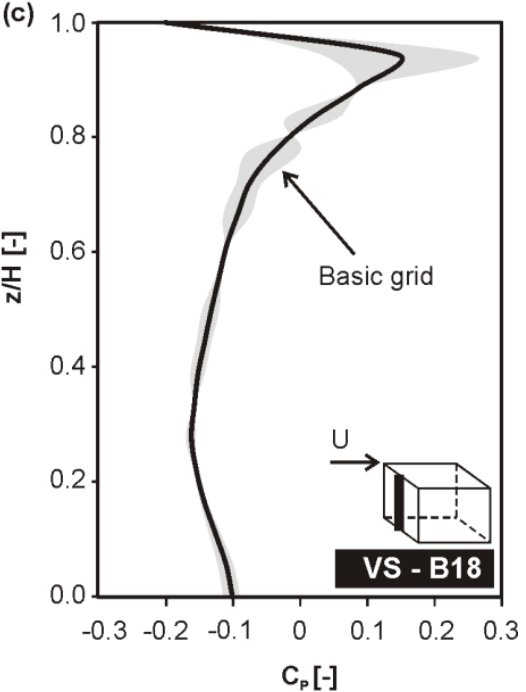

Figure 7. Grid-sensitivity analysis for VS-B18 (scaled 1:100): (a) vertical profile of streamwise wind speed along a vertical line in front of the central building (black) at position $\mathrm{P}$ calculated with coarse, basic and fine grid; (b) pressure coefficient along the vertical centerline at the windward facade of the central building calculated with coarse, basic and fine grid; (c) grid-induced error bands for the basic grid solution calculated using GCI proposed by Roache $[90,91]$.
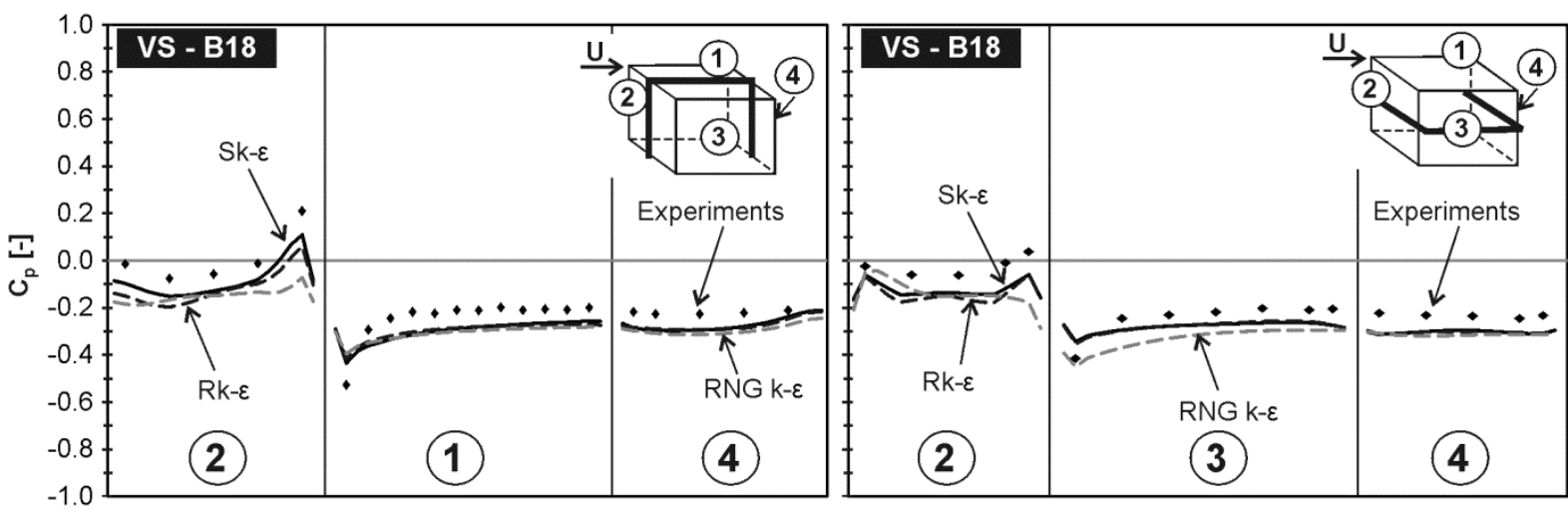

Figure 8. Pressure coefficient along vertical (a) and horizontal (b) centerlines at facades and roof of central building for VS-B18 (scaled 1:100) obtained from wind-tunnel measurements and CFD simulations with standard (Sk- $\varepsilon$ ),

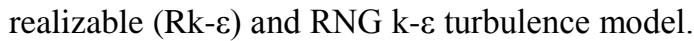




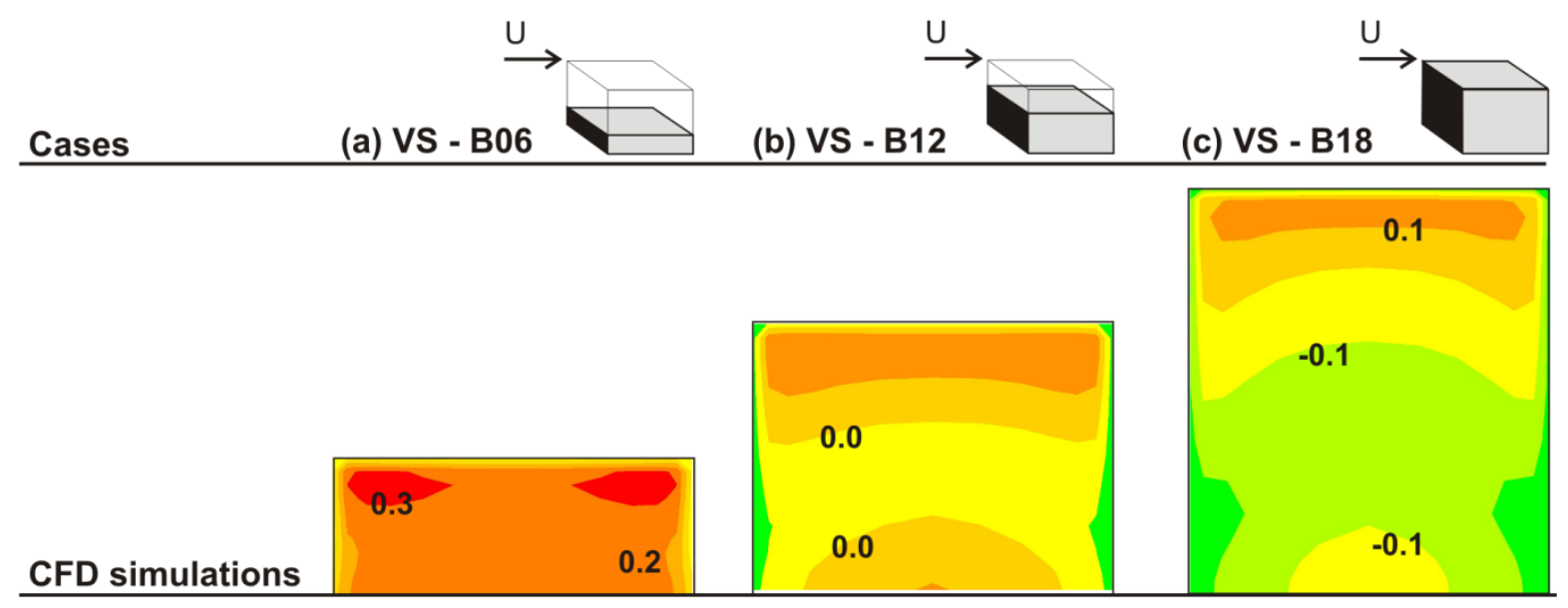

\section{Experiments}

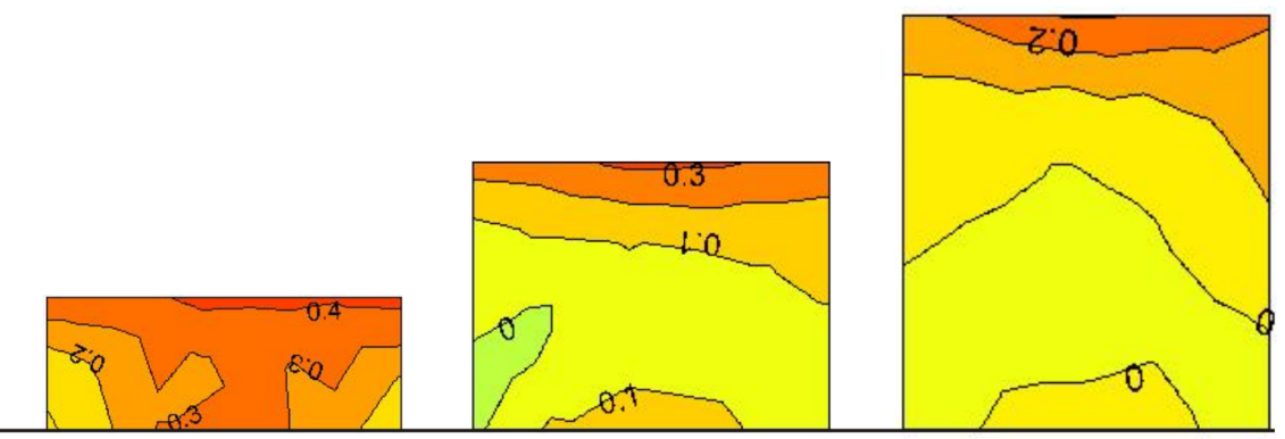

Figure 9. Pressure coefficient on the windward facade of the central building for (a) VS-B06, (b) VS-B12, and (c) VS-B18 by CFD simulations with standard $k-\varepsilon$ model and wind-tunnel measurements.

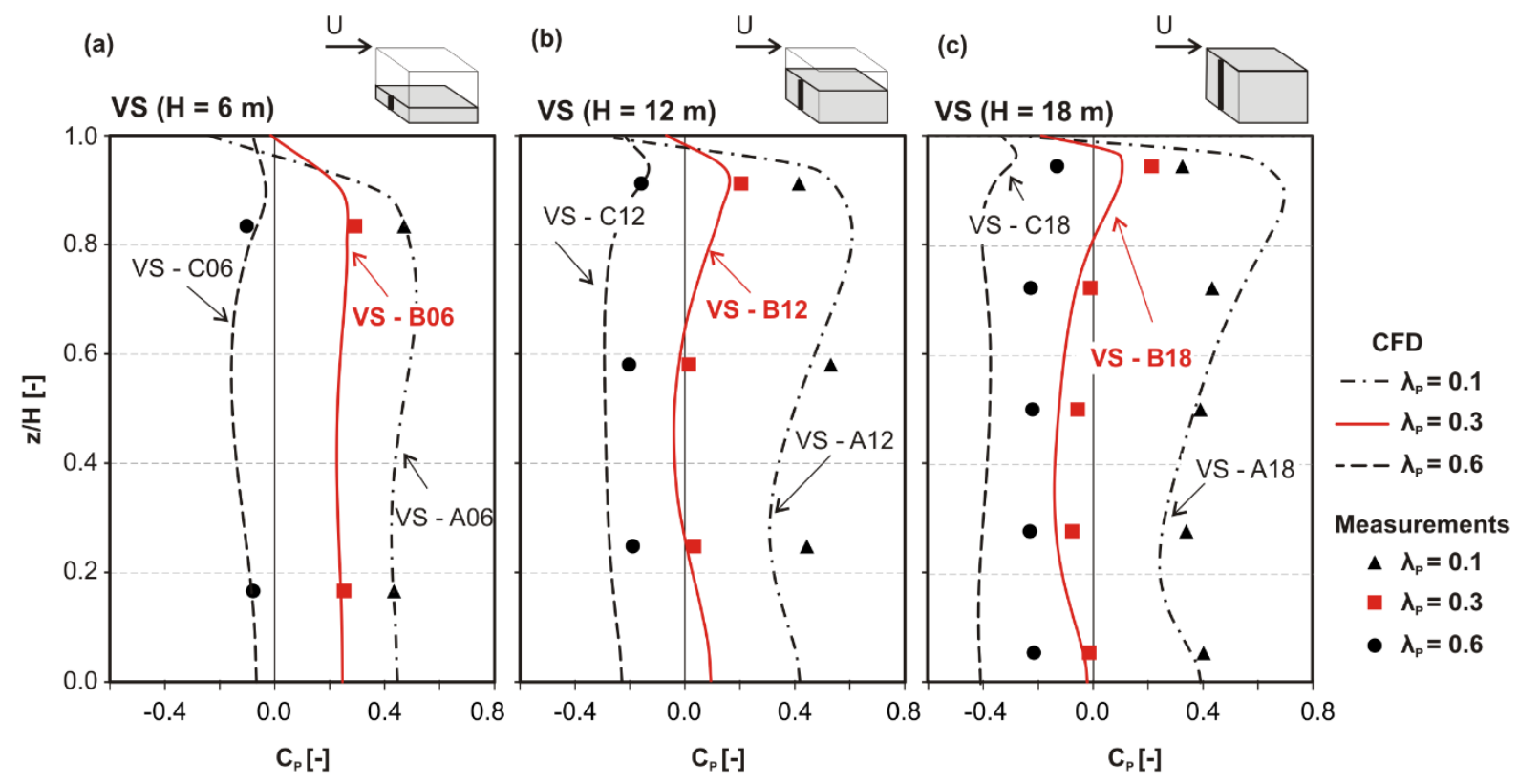

Figure 10. Pressure coefficient along the vertical centerline of the windward facade of the central building for VScases with $\mathrm{H}$ equal to (a) $6 \mathrm{~m}$, (b) $12 \mathrm{~m}$, and (c) $18 \mathrm{~m}$ obtained from CFD simulations with standard $\mathrm{k}-\varepsilon$ turbulence model and wind tunnel measurements. 


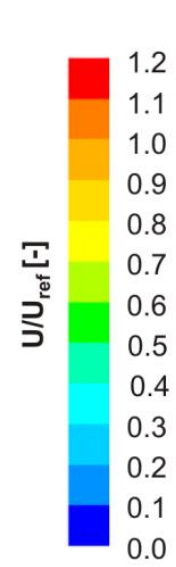

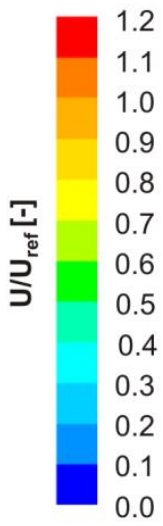

(a) MS-0 (H = 18m)

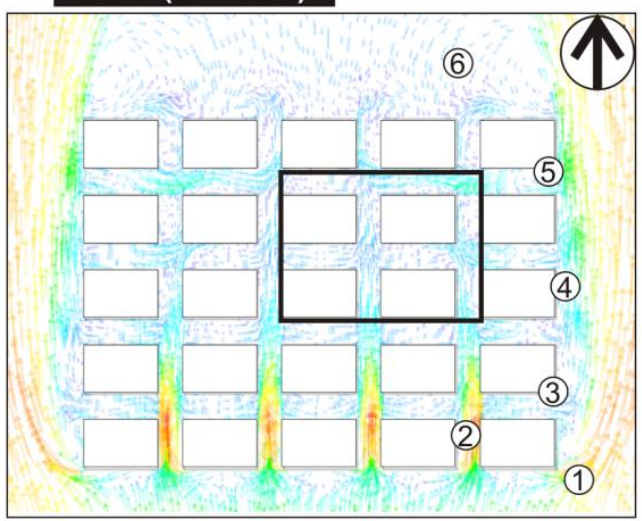

(c) $M S-2(H=18 m)$

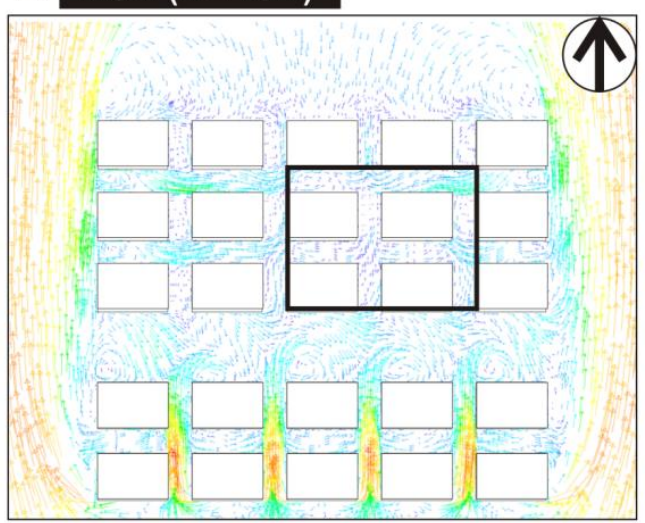

(b) $M S-0(H=18 m)$

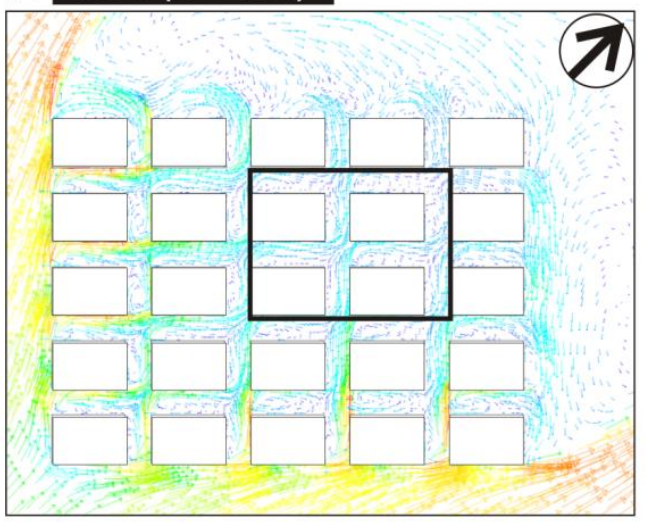

(d) $\operatorname{MS}-2(H=18 m)$

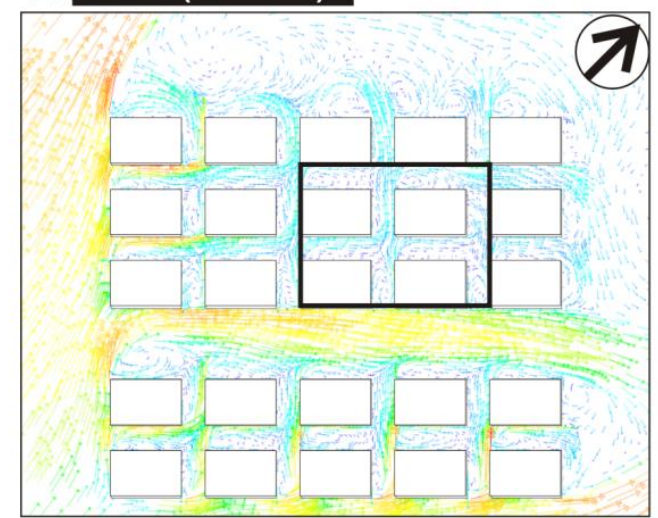

Figure 11. MS-cases: normalized velocity magnitude for (a) case MS- 0 for $45^{\circ}$, (b) case MS- 2 for $45^{\circ}$, (c) case MS0 for $90^{\circ}$, (d) case MS-2 for $90^{\circ}$. 

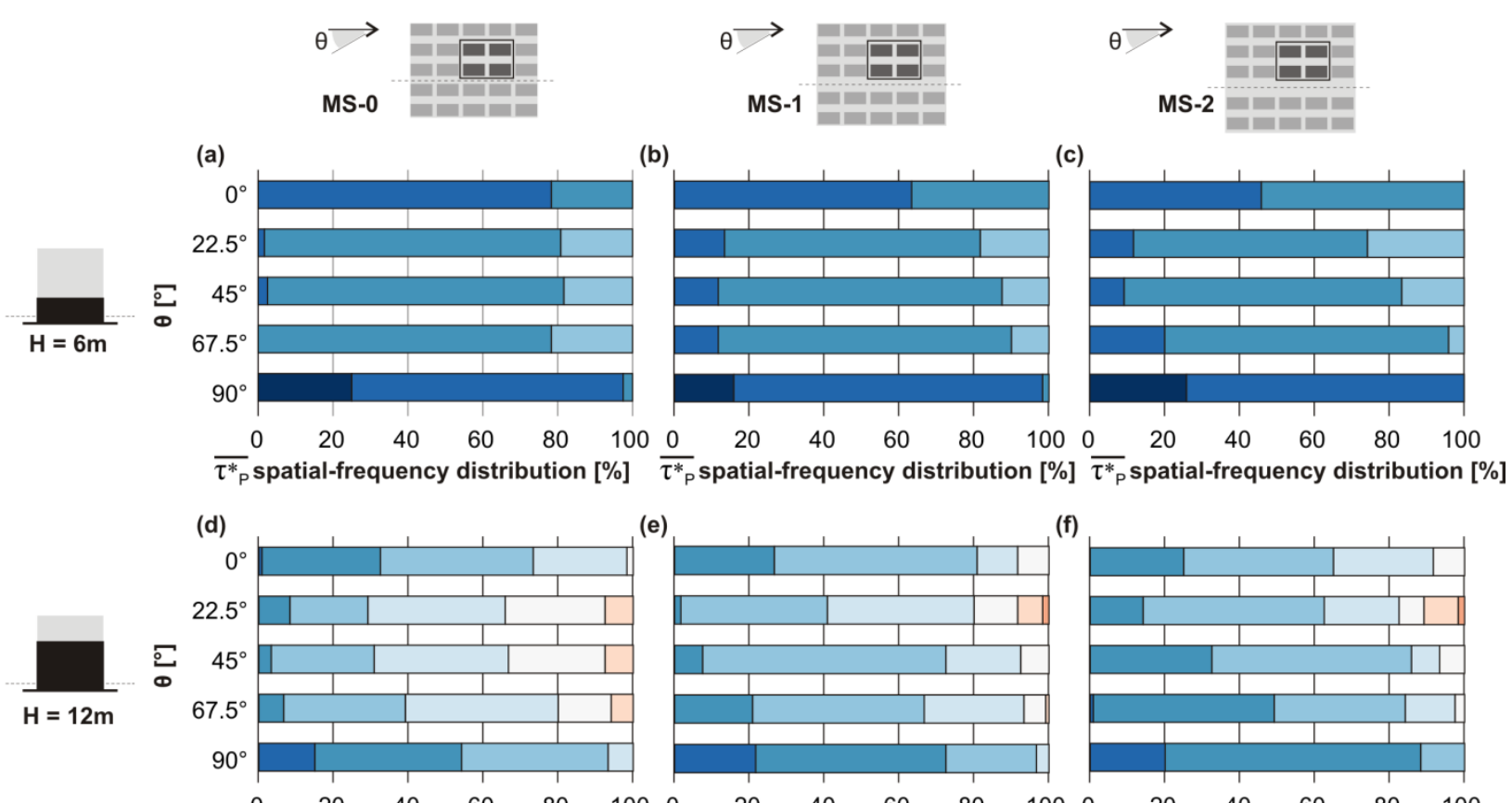

(e)

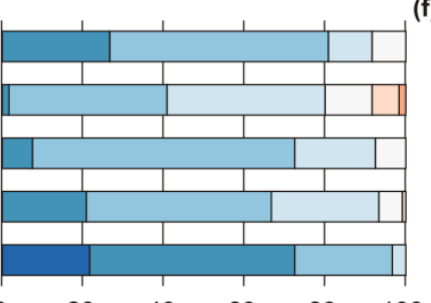

(f)

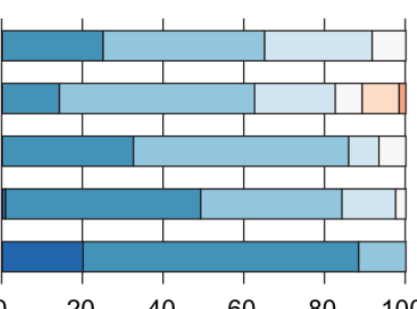

$\overline{\tau_{\mathrm{P}}}$ spatial-frequency distribution [\%] $\overline{\tau_{\mathrm{P}}}$ spatial-frequency distribution [\%] $\overline{\tau_{\mathrm{P}}}$ spatial-frequency distribution [\%]

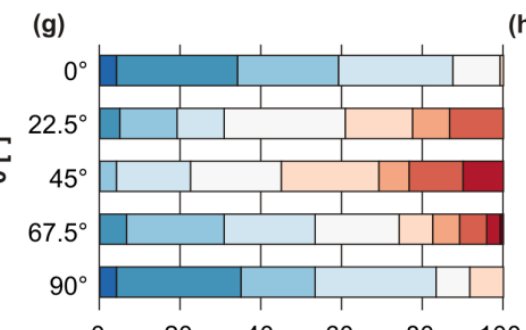

(h)

(I)
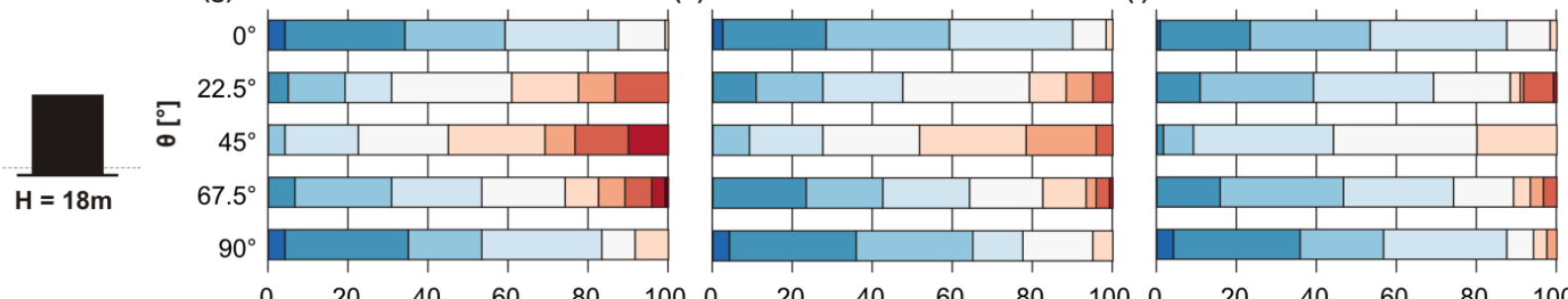

$\overline{\tau^{*}}$ spatial-frequency distribution [\%] $\overline{\tau^{*}}$ spatial-frequency distribution [\%] $\overline{\tau^{*}}$ spatial-frequency distribution [\%]

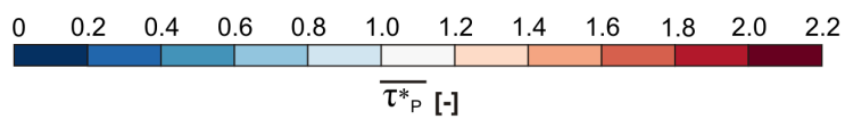

Figure 12. MS-cases: spatial-frequency distribution of the normalized local mean age of air in the area of interest for different wind directions and building height $\mathrm{H}=6 \mathrm{~m}$ (a,b,c), $12 \mathrm{~m}$ (d,e,f) and $18 \mathrm{~m}$ (g,h,i). 


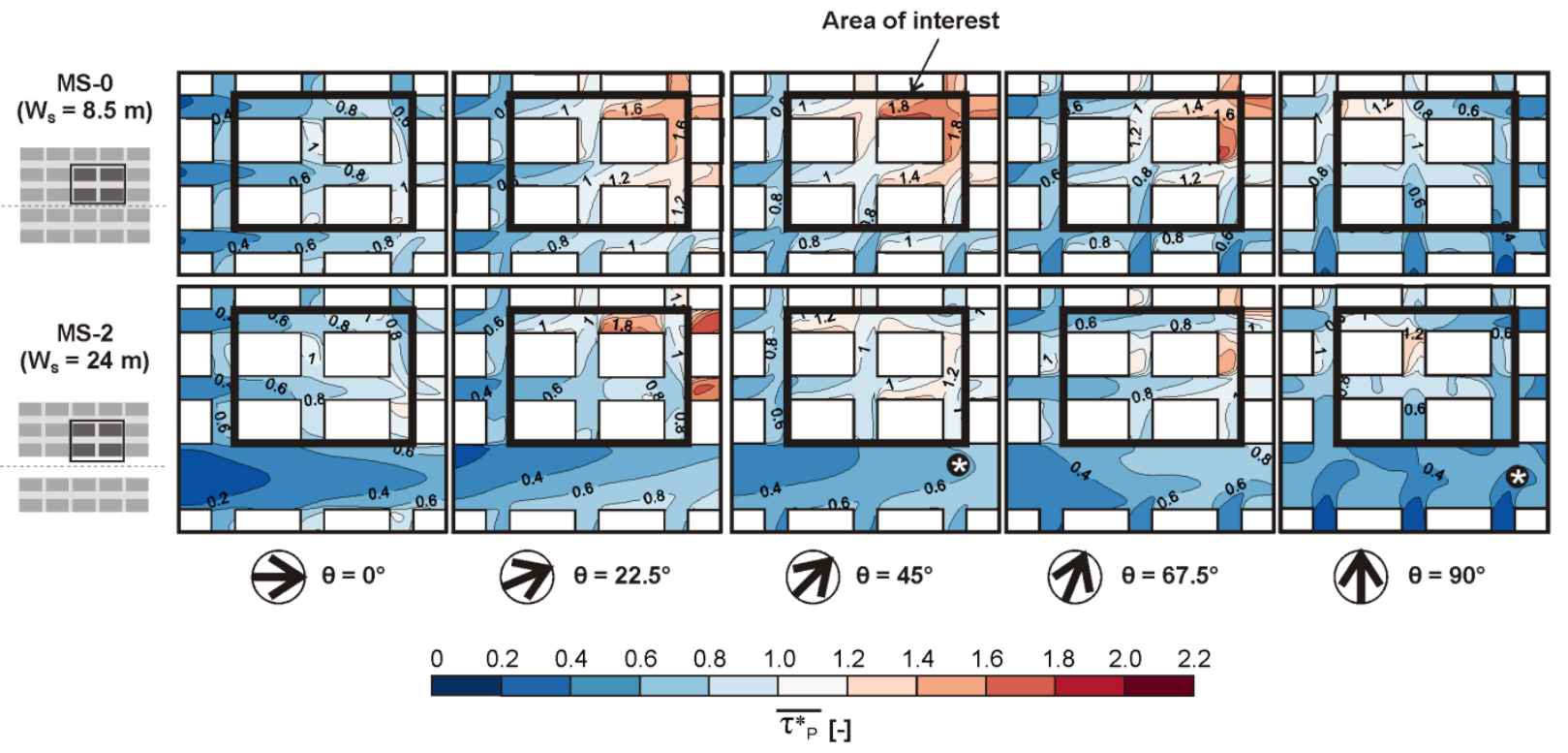

Figure 13. Contours of the normalized local mean age of air for the cases MS- 0 and MS-2 with $\mathrm{H}=18 \mathrm{~m}$ obtained for wind directions $0^{\circ}, 22.5^{\circ}, 45^{\circ}, 67.5^{\circ}$ and $90^{\circ}$. 